Case Report

\title{
Aligning Urban Policy with Climate Action in the Global South: Are Brazilian Cities Considering Climate Emergency in Local Planning Practice?
}

\author{
Debora Sotto ${ }^{1}$, Arlindo Philippi Jr. ${ }^{1}$, Tan Yigitcanlar ${ }^{2}$ **(D) and Md Kamruzzaman ${ }^{3}$ \\ 1 School of Public Health, University of São Paulo, Av. Dr. Arnaldo, 715 São Paulo, SP 01246-904, Brazil \\ 2 School of Civil Engineering and Built Environment, Queensland University of Technology, 2 George Street, \\ Brisbane QLD 4000, Australia \\ 3 Faculty of Art, Design and Architecture, Monash University, 900 Dandenong Road, Caulfield East, \\ VIC 3145, Australia \\ * Correspondence: tan.yigitcanlar@qut.edu.au; Tel.: +61-7-3138-2428
}

Received: 6 August 2019; Accepted: 3 September 2019; Published: 5 September 2019

\begin{abstract}
Climate change is the biggest global threat of our time. As a signatory nation of the Paris Agreement, Brazil has made a climate action commitment, and expressed its nationally determined contribution to reduce its greenhouse gas emissions by $37 \%$. The Brazilian population is highly urban, and Brazilian cities are mostly responsible for greenhouse gas emissions, and the worst effects of global warming are experienced in cities. Hence, the fulfillment of the Brazilian climate commitments depends on the active engagement of municipalities. Nevertheless, the Brazilian national government does not monitor local climate actions, and it is not clear how local urban policy is aligned with climate action. In order to bridge this gap, this study tackles the question of: "Are, and if yes how, cities considering the climate emergency in their local planning mechanisms?" This question is investigated by placing five major Brazilian cities under the microscope. The methodological approach includes literature review and applied qualitative analysis to scrutinize how climate issues and actions are factored in urban planning regulations to verify if and to what extent local policies contribute to the fulfillment of the Brazilian nationally determined contribution, and sustainable development goals. The results disclose that investigated cities have adequately incorporated climatic issues in their urban planning mechanisms. However, policy concentrates more on adaptation rather than mitigation, and policy implementation yet to be realized.
\end{abstract}

Keywords: climate change; climate emergency; climate crisis; global warming; sustainable urban development; sustainable development goals; smart cities; disasters; urban health; urban policy

\section{Introduction}

The Anthropocene, a geological era of human domination on Earth's resources, has generated many complex problems that threaten the well-being and existence of many species-including the human kind [1,2]. The single most important problem we face today, in the Anthropocene age, is climate change or more correctly the climate emergency or crisis [3,4]. The impacts, just to name a few, include more frequent and extreme heat episodes, rising seas and increased coastal flooding, longer and more damaging wildfire seasons, more destructive hurricanes, costly and growing health impacts, heavier precipitation and flooding, destruction of marine ecosystems, more severe droughts in some areas, increased pressure on groundwater supplies, melting ice cap, disruptions to food supplies, plant and animal range shifts, climate refugees, and changing seasons [5-7].

During the last few years, various solutions have been put forward to combat the problem, particularly targeting the unsustainable urban development and cleaner production [8-10]. These 
include adopting new development paradigms to make cities more sustainable, resilient, and smarter-e.g., smart city and smart urbanism movements [10,11] —and incentivizing green technology and cleaner industrial development [12-14]. However, the solutions targeting more sustainable urbanization and industrialization with limited emissions have not found wider application grounds across the globe, and also existing initiatives were not efficient enough to make a significant difference $[15,16]$.

There have been international and national platforms and initiative to intervene with the status quo, and also provide possible directions and solutions to combat the climate change problem-more correctly the factors causing it. For example, as nation signatories of the United Nations' Framework Convention on Climate Change (UNFCCC) and to the Paris Agreement [17] many countries have made the commitment, expressed in their nationally determined contribution (NDC), to reduce its greenhouse gas emissions (GHG) [18]. However, as most of the world population is urban, compliance with NDC depends on the engagement of local governments-i.e., municipalities [19]. Furthermore, it is required for cities to take firm action on climate adaptation and resilience promotion, as the worst effects of global warming-floods, droughts, landslides, epidemics-are experienced by the population at the local level, deeply affecting public health and quality of life, especially among the most vulnerable social sectors [20].

Engagement of cities across the world in tackling climate change, autonomously of their respective nation-states, is a relatively recent phenomenon [21-23], with significant and positive impacts on the latest accomplishments of international climate negotiations. Despite the lack of a legal status under the international law, cities have intensified their actions in international relations through the construction of networks, such as Local Governments for Sustainability (ICLEI), United Cities and Local Governments (UCLG), 40 Cities for Climate, and Compact of Mayors (C40 Group), active in sustainable urban development, and climate change. As a result, cities have been identified as key actors for environmental protection and sustainable development-firstly participating in UNFCCC Conferences as 'observant organizations,' and from the 2010 Conference of the Parties (COP-16) onward as "governmental actors".

The final declaration of the United Nations Conference on Sustainable Development (Rio +20), "The Future We Want" [24], has reaffirmed the strategic role of cities in promoting sustainable development. The Rio +20 declaration also set out the commitment to formulate "sustainable development goals" (SDGs), replacing the "millennium development goals" (MDGs). These SDGs were issued in September 2015 [25] a set of 17 main goals, broken down into 169 targets and monitored by correspondent indicators, to be pursued by all nations, regardless of their developmental stage.

The sustainable development goal (SDG) no. 13 (SDG-13) refers specifically to "climate action", expressing the global commitment to take urgent action on climate change and its impacts within the UNFCCC framework. SDG Target 13.B fosters capacity building, promotion for productive climate change-related planning and management in local communities in the least developed countries, as well as women, youth, and vulnerable minorities. SDG-11, on the other hand, expresses the commitment to make cities and human settlements safe, resilient, and sustainable. Among the foreseen axes of action, Target 11.B establishes the goal to substantially increase, by 2020, the number of cities and human settlements adopting and implementing integrated policies and plans towards inclusion, resource efficiency, mitigation and adaptation to climate change and resilience to disasters, in line with the Sendai Framework for Disaster Risk Reduction (2015-2030)—-the first major international agreement of the post-2015 development agenda.

Both SDG-11 and 13 strongly connect to strategic goals and actions established by the 2016 "new urban agenda" (NUA), approved in the city of Quito (Ecuador) [26]. NUA expressly envisions cities and human settlements that adopt and implement disaster risk reduction and management, reduce vulnerability, build resilience and responsiveness to natural and human-made hazards, and promote mitigation and adaptation to climate change. By doing so, NUA highlights the mandatory 
connection existing between SDG-13 (action against global climate change), SDG-11 (sustainable cities and communities), and SDG-3 (health and well-being).

Not only SDG-3, health and well-being, is indispensable for the quality of life in cities, but it is also a central component in the construction of urban resilience. In this sense, Target 3.D commits the nation-states to strengthen the capacity of all countries, and also local governments, for early warning, reduction, and management of these risks, considering the increasing national and global risks associated with extreme climatic events.

It is important to stress that the most vulnerable social segments, which already have the worst housing and sanitation conditions and the worst levels of access to essential services, including health, are also the most exposed to the adverse effects of extreme weather events and other shocks [27-29]. Hence the commitment expressed by Target 1.E, deployed from SDG-1, eradicating poverty, to build the resilience of the poor and those in a vulnerable situation and to reduce their exposure and vulnerability to extreme events, shocks, and disasters. In an increasingly urban world, building the resilience of the poorest and most vulnerable is one of the significant challenges to be faced by urban planners and managers.

Against this backdrop, the aim of this study is to examine how cities, and particularly cities in the global south (an emerging term used by the World Bank to refer to countries located in Asia, Africa, Latin America (including Brazil), and the Caribbean and considered to have low- and middle-income levels [30]), are considering the climate emergency in their local planning mechanisms. The study concentrates on Brazil as the case study context, and places five major Brazilian cities-i.e., Manaus, Salvador, Goiânia, São Paulo, and Curitiba-under the microscope to address the research aim. The methodology of the investigation contains undertaking a literature review, collecting public policy data, and conducting a quantitative analysis. The paper is structured as follows: After this introduction section, Section 2 presents materials and methods. Section 3 discloses the results. Section 4 discusses the findings, and Section 5 concludes the paper.

\section{Materials and Methods}

\subsection{Case Study}

The study selects Brazil as a relevant country context from the global south-with vast land, large population, pristine natural assets, and a big appetite for economic growth-to explore how well local urban policy is aligned with climate action [31]. The research is developed as a multiple case study [32]. It involved literature review, data collection in digital repositories, and the qualitative analysis of the data using a content analysis software-i.e., NVivo [33]. As it would not be possible to study all 5570 Brazilian municipalities, in order to cover the different realities and main biomes of Brazilian territory, five major Brazilian cities were targeted to be selected for the analysis at the ratio of one city per each region of the country-i.e., North, Northeast, Midwest, Southeast, and South.

The case study selection process obeyed the following criteria: (a) Population above 500,000 people (the Brazilian Institute of Geography and Statistics (IBGE) classifies Brazilian cities in three categories: small (less than 100,000 inhabitants); medium (more than 100,000 inhabitants and less than 500,000 inhabitants) and large (more than 500,000 inhabitants. IBGE's methodology does not divide large cities in any other additional categories. Large cities in Brazil are more typically "urban" than medium and small cities, which is why this investigation opted to select only cities with more than 500,000 inhabitants); (b) Local environmental bodies and councils, according to 1981 National Environmental Policy [34]; (c) Existence of a Master Plan, approved accordingly to 2001 Statute of the City [35]; (d) City's participation in at least one of the following international city networks, selected for their outstanding performance in the field of climate change: Local Governments for Sustainability (ICLEI), Mercociudades, as representative of the Communities and United Local Governments in South America (UCLG), and C40 Group, and; (e) Availability of data and information pertinent to municipal management and planning, accessible through the Internet. Based on these criteria (Table 1), 
the following cities were selected as the object of the case study: Goiânia (Central-West Region), Salvador (Northeast Region), Manaus (North Region), São Paulo (Southeast Region) (in Brazil, all municipalities with more than 500,000 inhabitants must follow the same institutional framework as cities with a population of one million, two million or 12 million people. Therefore, the fact that São Paulo is significantly larger than the other selected cities does not distort or affect the results of the proposed investigation.), and Curitiba (Southern Region) (Brasília, capital city of the nation, was excluded from the selection process because, as the seat of the Federal District, it presents unique institutional characteristics, distinct from the other Brazilian municipalities). As seen in Table 1, despite listed similarities, the case cities are in different sizes and characteristics, thus a one-on-one comparison would not be a correct approach [36]. Here the purpose is to capture the general trends related to climate policy in Brazilian cities. Hence, having cities with different attributes is valid approach to address the research question [37].

Table 1. Case study cities' salient characteristics.

\begin{tabular}{|c|c|c|c|c|c|}
\hline City & Population & $\begin{array}{c}\text { Environmental } \\
\text { Body and } \\
\text { Council }\end{array}$ & $\begin{array}{l}\text { Master Plan in } \\
\text { Accordance with the } \\
\text { Statute of the City }\end{array}$ & $\begin{array}{l}\text { City's } \\
\text { Networks }\end{array}$ & $\begin{array}{l}\text { Data Available } \\
\text { on the Internet }\end{array}$ \\
\hline $\begin{array}{c}\text { Goiânia } \\
\text { State of Goiás } \\
\text { Midwest Region }\end{array}$ & $1,466,105$ & Yes & 2007 & ICLEI UCLG & Yes \\
\hline $\begin{array}{c}\text { Salvador } \\
\text { State of Bahia } \\
\text { Northeast Region }\end{array}$ & $2,953,986$ & Yes & 2016 & $\begin{array}{c}\text { C40 } \\
\text { ICLEI UCLG }\end{array}$ & Yes \\
\hline $\begin{array}{c}\text { Manaus } \\
\text { State of Amazonas } \\
\text { North Region }\end{array}$ & $2,130,264$ & Yes & 2014 & ICLEI & Yes \\
\hline $\begin{array}{c}\text { São Paulo } \\
\text { State of São Paulo } \\
\text { Southwest Region }\end{array}$ & $12,106,920$ & Yes & 2014 & $\begin{array}{l}\text { C40 } \\
\text { ICLEI } \\
\text { UCLG }\end{array}$ & Yes \\
\hline $\begin{array}{l}\text { Curitiba } \\
\text { State of Paraná } \\
\text { South Region }\end{array}$ & $1,908,359$ & Yes & 2015 & $\begin{array}{l}\text { C40 } \\
\text { ICLEI } \\
\text { UCLG }\end{array}$ & Yes \\
\hline
\end{tabular}

\subsection{Methodology and Data}

Assuming that an effective climate policy at any level must take as its starting point the findings of GHG emissions inventories, we firstly collected the inventories drawn up by the surveyed cities, in order to compare their findings with Emission Inventories edited by the respective states and 2010 and 2015 national emissions inventories issued by the Brazilian government. The policy document search was organized according to four areas, or climate action axis: (a) Mitigation; (b) Adaptation; (c) Resilience as defined by the IPCC [38], and; (d) Cooperation (cooperation viewed as decentralized cooperation, or city's diplomacy, comprehending agreements celebrated between cities and any other international actors, such as other cities, other countries, international organizations, as well as actions developed within the context of city's international networks). Table 2 presents local policies, plans, programs, and projects, classified according to the four climate action axes of mitigation, adaptation, resilience, and cooperation.

The documents, compiled by the researchers in the first quarter of 2018 in official digital data bases (In Brazil, due to national law provisions, all federative entities, municipalities included, must provide free access to all public interest information. In compliance, the union (federation), states and most of the large municipalities have made their legislation (laws and regulations) available online, in official digital databases), and organized by city and topic and listed in Table 3. Compiled documents were processed with NVivo, firstly sorted out in cases, each case corresponding to one of the investigated cities as well as to the nation. The word search tool was used to find references to the four axes of climate action-i.e., adaptation, cooperation, mitigation, and resilience-in the texts of the compiled documents. The word search tool was also used to locate references, in the local documents, to national 
regulations related to climate change-e.g., National Emissions Inventory, 2009 National Climate Change Policy (PNMC), 2016 National Adaptation Plan (PNA), Brazil's NDC, 2013 Sectoral Health Plan for Climate Change Mitigation and Adaptation, and 2012 National Protection and Civil Defense Policy (PNPDEC). All policy documents were in Portuguese language. Analyses were conducted in Portuguese, and the results were translated into English.

Table 2. Local policies, plans, programs, and projects.

\begin{tabular}{|c|c|c|c|}
\hline Mitigation & Adaptation & Resilience & Cooperation \\
\hline $\begin{array}{l}\text { GHG emissions } \\
\text { inventories }\end{array}$ & $\begin{array}{l}\text { GHG emissions } \\
\text { inventories }\end{array}$ & $\begin{array}{l}\text { GHG emissions } \\
\text { inventories }\end{array}$ & City networks \\
\hline Master plan & Master plan & Master plan & Master plan \\
\hline Land use regulations & Land use regulations & Land use regulations & $\begin{array}{c}\text { Decentralized } \\
\text { cooperation }\end{array}$ \\
\hline Housing local plan & Housing local plan & Housing local plan & $\begin{array}{c}\text { Decentralized } \\
\text { cooperation }\end{array}$ \\
\hline Mobility local plan & Mobility local plan & Mobility local plan & $\begin{array}{c}\text { Decentralized } \\
\text { cooperation }\end{array}$ \\
\hline Sanitation local plan & Sanitation local plan & Sanitation local plan & $\begin{array}{c}\text { Decentralized } \\
\text { cooperation }\end{array}$ \\
\hline Waste management plan & Waste management plan & Waste management plan & $\begin{array}{l}\text { Decentralized } \\
\text { cooperation }\end{array}$ \\
\hline Drainage local plan & Drainage local plan & Drainage local plan & $\begin{array}{c}\text { Decentralized } \\
\text { cooperation }\end{array}$ \\
\hline Public health local plan & Public health local plan & Public health local plan & $\begin{array}{c}\text { Decentralized } \\
\text { cooperation }\end{array}$ \\
\hline Climate mitigation plan & Climate adaptation plan & $\begin{array}{l}\text { Disasters management } \\
\text { plan }\end{array}$ & $\begin{array}{l}\text { Decentralized } \\
\text { cooperation }\end{array}$ \\
\hline
\end{tabular}

We have used the AND, OR, NEAR, $\left({ }^{*}\right)$, REQUIRED, FUZZY and (") operators in at least five successive rounds of word search queries in order to obtain more precise results, avoiding redundancies, ambiguities, and false positive results (NVivo, as qualitative analysis tool, allows the election of objective criteria and comparison standards for data contained in large masses of text. The obtained results present a satisfactory degree of precision for the proposed analysis, but not, of course, absolute precision, as despite the efforts to reduce the investigated topics to expressions as accurate and straightforward as possible, some inconsistencies have persisted, mostly due to redundancies and ambiguities typical of the Portuguese language). The references obtained in the word search rounds were grouped in four nodules, corresponding to each of the climate action axes: Adaptation, Cooperation, Mitigation, and Resilience, as well as a fifth node, devoted to the identification of possible connections between public health and other local policies (Table 4). Lastly, several rounds of queries were performed, crossing the evidence compiled in each node with the cases, thus obtaining results that are further discussed in order to offer some insights. 
Table 3. Compiled policy documents organized by city and topic.

\begin{tabular}{|c|c|c|c|c|c|c|}
\hline \multirow{2}{*}{ Topic } & \multirow{2}{*}{ Type } & \multicolumn{5}{|c|}{ City } \\
\hline & & CURITIBA & GOIÂNIA & MANAUS & SALVADOR & SÃO PAULO \\
\hline \multirow[t]{4}{*}{ Climate } & $\begin{array}{l}\text { Emissions } \\
\text { Inventory }\end{array}$ & $\begin{array}{l}2013 \text { Emissions } \\
\text { Inventory-3rd Edition }\end{array}$ & $\begin{array}{c}2016 \text { Emissions } \\
\text { Inventory-2nd Edition }\end{array}$ & & $\begin{array}{l}2013 \text { Emissions } \\
\text { Inventory—-1st Edition }\end{array}$ & $\begin{array}{l}2009 \text { Emissions } \\
\text { Inventory-2nd Edition }\end{array}$ \\
\hline & Plan & 2009 Climate Action Plan & 2011 Sustainable Goiânia & $\begin{array}{l}\text { The Card of } \\
\text { Amazonia }\end{array}$ & Coastal Management Plan & $\begin{array}{l}2009 \text { Climate Change } \\
\text { Municipal Policy }\end{array}$ \\
\hline & $\begin{array}{l}\text { Legislation/ } \\
\text { Report }\end{array}$ & $\begin{array}{l}\text { 2016 Curitiba Strategic } \\
\text { Actions: Climate and } \\
\text { Resilience }\end{array}$ & $\begin{array}{l}2016 \text { Local Policy on the } \\
\text { Prevention, Reduction and } \\
\text { Compensation of } \mathrm{CO}_{2} \text { and } \\
\text { Other Vehicular Emissions }\end{array}$ & $\begin{array}{l}2011 \text { Environmental } \\
\text { Code (proxy to a local } \\
\text { climate plan) }\end{array}$ & $\begin{array}{l}2015 \text { Sustainable Development } \\
\text { and Innovation Incentives } \\
\text { Municipal Program }\end{array}$ & \\
\hline & Report & $\begin{array}{c}2014 \text { Curitiba's } \\
\text { Environmental and } \\
\text { Socio-Economic } \\
\text { Vulnerabilities Evaluation }\end{array}$ & & & $\begin{array}{l}2015 \text { Environmental and } \\
\text { Sustainable Development } \\
\text { Municipal Policy }\end{array}$ & \\
\hline Urban Planning & Plan & 2015 Master Plan & 2007 Master Plan & 2014 Master Plan & 2016 Master Plan & 2014 Master Plan \\
\hline \multirow[t]{3}{*}{$\begin{array}{c}\text { Land Use } \\
\text { Regulations }\end{array}$} & Legislation & 2000 Land Use Regulations & 1994 Urban Zoning & $\begin{array}{l}2014 \text { Land Use } \\
\text { Legislation }\end{array}$ & 2016 Land Use Regulations & $\begin{array}{l}2016 \text { Zoning and Land Use } \\
\text { Regulations }\end{array}$ \\
\hline & & & 2008 Environmental Zoning & $\begin{array}{l}2014 \text { Urban Perimeter } \\
\text { Legislation }\end{array}$ & 2017 Building Code & 2017 Building Code \\
\hline & & & 2008 Building Code & 2014 Building Code & & \\
\hline Housing & Plan & $\begin{array}{l}\text { Social Housing Municipal } \\
\text { Plan }\end{array}$ & Provisions on Social Housing & & $\begin{array}{l}\text { 2008-2015 Municipal Housing } \\
\text { Plan }\end{array}$ & Municipal Housing Plan \\
\hline \multirow[t]{2}{*}{ Mobility } & $\begin{array}{l}\text { Legislation/ } \\
\text { Plan }\end{array}$ & $\begin{array}{l}\text { 2014-2017 Urban Mobility } \\
\text { Plan }\end{array}$ & Urban Mobility Plan & $\begin{array}{l}2015 \text { Urban Mobility } \\
\text { Plan }\end{array}$ & $\begin{array}{l}2018 \text { Sustainable Urban } \\
\text { Mobility Municipal Plan }\end{array}$ & 2015 Urban Mobility Plan \\
\hline & & & & & & $\begin{array}{c}2001 \text { Municipal } \\
\text { Transportation System }\end{array}$ \\
\hline \multirow[t]{3}{*}{ Sanitation } & Plan & $\begin{array}{l}2017 \text { Sanitation Municipal } \\
\text { Plan }\end{array}$ & Municipal Sanitation Plan & $\begin{array}{l}2014 \text { Municipal } \\
\text { Sanitation Plan }\end{array}$ & $\begin{array}{l}\text { 2010-2011 Municipal } \\
\text { Sanitation Plan }\end{array}$ & $\begin{array}{l}\text { 2010-2030 Municipal } \\
\text { Sanitation Plan }\end{array}$ \\
\hline & & $\begin{array}{l}2017 \text { Water Distribution } \\
\text { Municipal Plan }\end{array}$ & & & & \\
\hline & & 2017 Sewage Municipal Plan & & & & \\
\hline
\end{tabular}


Table 3. Cont

\begin{tabular}{|c|c|c|c|c|c|c|}
\hline \multirow{2}{*}{ Topic } & \multirow{2}{*}{ Type } & \multicolumn{5}{|c|}{ City } \\
\hline & & CURITIBA & GOIÂNIA & MANAUS & SALVADOR & SÃO PAULO \\
\hline $\begin{array}{c}\text { Waste } \\
\text { Management }\end{array}$ & Plan & $\begin{array}{l}2017 \text { Waste Management } \\
\text { Municipal Plan }\end{array}$ & $\begin{array}{l}2014 \text { Waste Management } \\
\text { Local Plan }\end{array}$ & $\begin{array}{c}2010 \text { Waste } \\
\text { Management } \\
\text { Municipal Plan }\end{array}$ & $\begin{array}{c}2012 \text { Waste Management } \\
\text { Municipal Plan }\end{array}$ & $\begin{array}{l}2014 \text { Waste Management } \\
\text { Municipal Plan }\end{array}$ \\
\hline Drainage & Plan & 2017 Urban Drainage Plan & 2014 Drainage Regulations & & & $\begin{array}{l}2012 \text { Drainage and Rainwater } \\
\text { Management Manual }\end{array}$ \\
\hline \multirow[t]{3}{*}{$\begin{array}{c}\text { Disasters } \\
\text { Management }\end{array}$} & $\begin{array}{l}\text { Legislation/ } \\
\text { Plan }\end{array}$ & $\begin{array}{l}\text { Municipal Civil Defense } \\
\text { System }\end{array}$ & $\begin{array}{l}\text { 1998/2010 Municipal Civil } \\
\text { Defense System }\end{array}$ & $\begin{array}{l}\text { 2014-2017 Municipal } \\
\text { Public Health Plan }\end{array}$ & 2015 Rain Contingency Plan & $\begin{array}{l}2006 \text { Municipal Civil Defense } \\
\text { System }\end{array}$ \\
\hline & & & & & 2017 Urban Arborization Plan & \\
\hline & & & & & 2013 Civil Defense System & \\
\hline Public Health & Plan & $\begin{array}{l}\text { 2018-2021 Municipal Public } \\
\text { Health Plan }\end{array}$ & $\begin{array}{c}\text { 2014/2017 Municipal Public } \\
\text { Health Plan }\end{array}$ & $\begin{array}{l}\text { 2014-2017 Municipal } \\
\text { Public Health Plan }\end{array}$ & $\begin{array}{l}\text { 2018-2021 Municipal Public } \\
\text { Health Plan }\end{array}$ & $\begin{array}{l}\text { 2014-2017 Municipal Public } \\
\text { Health Plan }\end{array}$ \\
\hline $\begin{array}{l}\text { International } \\
\text { Cooperation }\end{array}$ & $\begin{array}{c}\text { Legislation/ } \\
\text { Platform/ } \\
\text { Agreement }\end{array}$ & $\begin{array}{c}\text { Participation in city's } \\
\text { networks: ICLEI, CGLU, C40; } \\
\text { International Affairs } \\
\text { Secretariat reports; Nazca } \\
\text { platform }\end{array}$ & $\begin{array}{c}\text { Participation in Cities } \\
\text { Networks: ICLEI, CGLU, } \\
\text { UBERLAC, Sustainable and } \\
\text { Emergent Cities Initiative; } \\
\text { International Affairs } \\
\text { Municipal Advisory reports; } \\
\text { Nazca Platform; Vulnerability } \\
\text { Assessment (UNFCCC } \\
\text { Adaptation Platform) }\end{array}$ & $\begin{array}{l}\text { Participation in City's } \\
\text { Networks: ICLEI; } \\
\text { Nazca Platform; } \\
\text { Municipality's reports }\end{array}$ & $\begin{array}{c}\text { Participation in City's } \\
\text { Networks: ICLEI, CGLU, C40; } \\
\text { Nazca Platform; Decentralized } \\
\text { cooperation agreements }\end{array}$ & $\begin{array}{l}\text { Participation in City's } \\
\text { Networks: ICLEI, CGLU, } \\
\text { C40; International Affairs } \\
\text { Secretariat Reports }\end{array}$ \\
\hline
\end{tabular}


Table 4. NVivo codebook.

\begin{tabular}{|c|c|}
\hline Node & Expressions \\
\hline Climate change & $\begin{array}{c}\text { “mudança climática" OR “mudanças climáticas" OR “mudança do } \\
\text { clima" OR “mudanças do clima” OR “alteração do clima” OR } \\
\text { "alterações do clima" OR “alteração climática" OR “alterações } \\
\text { climáticas" }\end{array}$ \\
\hline Adaptation & Adaptaç* \\
\hline Risk & Risco $^{*}$ \\
\hline Vulnerability & Vulnerabilidade OR vulnerave* \\
\hline Water & Água OR "recursos hídricos" OR permeabilidade OR drenagem \\
\hline International agreements & $\begin{array}{c}\text { "acordo internacional" OR “acordos internacionais" OR “cooperação } \\
\text { internacional" OR “cooperação descentralizada"OR "relações } \\
\text { internacionais" OR “internacionalização" }\end{array}$ \\
\hline International financing & "financiamento internacional" OR "financiamentos internacionais" \\
\hline International organizations & $\begin{array}{c}\text { “organização internacional” OR “organizações internacionais" Or } \\
\text { “agência internacional” OR “agências internacionais" OR “ONU” OR } \\
\text { "HABITAT” OR “Banco Mundial” Or “Banco Interamericano de } \\
\text { Desenvolvimento" OR “BID” OR “World Bank" OR “Organização } \\
\text { Mundial da Saúde” }\end{array}$ \\
\hline International networks & $\begin{array}{l}\text { "rede internacional" OR "redes internacionais" Or "ICLEI" OR "CGLU" } \\
\text { OR "C40" }\end{array}$ \\
\hline NDC & Ndc OR indc \\
\hline PNA & $\begin{array}{c}\text { PNA OR “Plano Nacional de Adaptação" OR "Plano Nacional de } \\
\text { Adaptação à Mudança do Clima" }\end{array}$ \\
\hline PNMC & $\begin{array}{l}\text { "política nacional sobre mudanças do clima" OR "política nacional } \\
\text { sobre mudança do clima"OR "política nacional de mudanças climáticas" } \\
\text { OR "política nacional de mudança do clima" OR "PNMC" }\end{array}$ \\
\hline Global warming & "aquecimento global" \\
\hline Greenhouse effect & "efeito estufa" \\
\hline Carbon emissions & “emissão de carbono" OR “emissão de gases" OR "emissões" \\
\hline Energy & energia \\
\hline Mitigation & Mitig* \\
\hline Pollution & poluição \\
\hline Resilience & Resiliência OR resiliente* \\
\hline PNPDEC & $\begin{array}{c}\text { "política nacional de proteção e defesa civil" OR PNPDEC OR “Sistema } \\
\text { Nacional de Proteção e Defesa Civil" OR SINPDEC OR “Conselho } \\
\text { Nacional de Proteção e Defesa Civil" OR CONPDEC }\end{array}$ \\
\hline Disaster & Desastre $^{*}$ OR enchente* OR escorregamento* OR seca* OR INCÊNDIO* \\
\hline Extreme events & $\begin{array}{l}\text { "evento extremo" OR “eventos extremos" OR “evento climático } \\
\text { extremo" OR “eventos climáticos extremos" OR evento*+extremo* }\end{array}$ \\
\hline Resilience & Resiliência OR resiliente* \\
\hline $\begin{array}{l}\text { Sectoral public health plan for } \\
\text { climate change mitigation and } \\
\text { adaptation }\end{array}$ & $\begin{array}{l}\text { "plano sectorial da saúde para mitigação e adaptação à mudança do } \\
\text { clima" OR "PSMC-Saúde" OR "plano setorial da saúde para mitigação } \\
\text { adaptação às mudanças climáticas" OR "plano sectorial da saúde para } \\
\text { mitigação e adaptação à mudança climática" }\end{array}$ \\
\hline Health & saúde \\
\hline
\end{tabular}




\section{Results}

\subsection{National, State, and Local GHG Emissions}

The Brazilian government, through the Ministry of Communications, Technology, Innovation, and Science (MCTIC) has been inventorying national GHG emissions since 1991. The 3rd National Inventory, published in 2016, with data up to 2010, indicates that the economic sectors responsible for the majority of the national emissions are "Agriculture", with 33\% and "Energy", with 29\%-e.g., Brazil is world's biggest ethanol producer [39]—followed closely by "Land Use and Forests", with 27\% of the total emissions. "Industrial Processes" and "Waste Treatment" respectively account for 7\% and $4 \%$ of the national emissions (Figure 1). The estimated total emissions for 2010 , calculated by the IPCC 2006 methodology (GWP-SAR), was 1,364,197 GtCO2e [40].

Data from the National Emission Register System (SIRENE) compiled in preparation for the 4th National Inventory indicates slightly higher emissions for the year 2015: 1,368,000 GtCO2e in total, but still well below the emission limit set in Brazil's NDC of 2,068,000 GtCO2e for 2020. The "Energy" sector, with 33\% of emissions, seems to have surpassed the "Agriculture" sector, with 31\% of emissions, followed by the "Land Use" sector, with 24\%, "Industrial Processes" with 7\% and "Waste Treatment", with $5 \%$ (Figure 1).

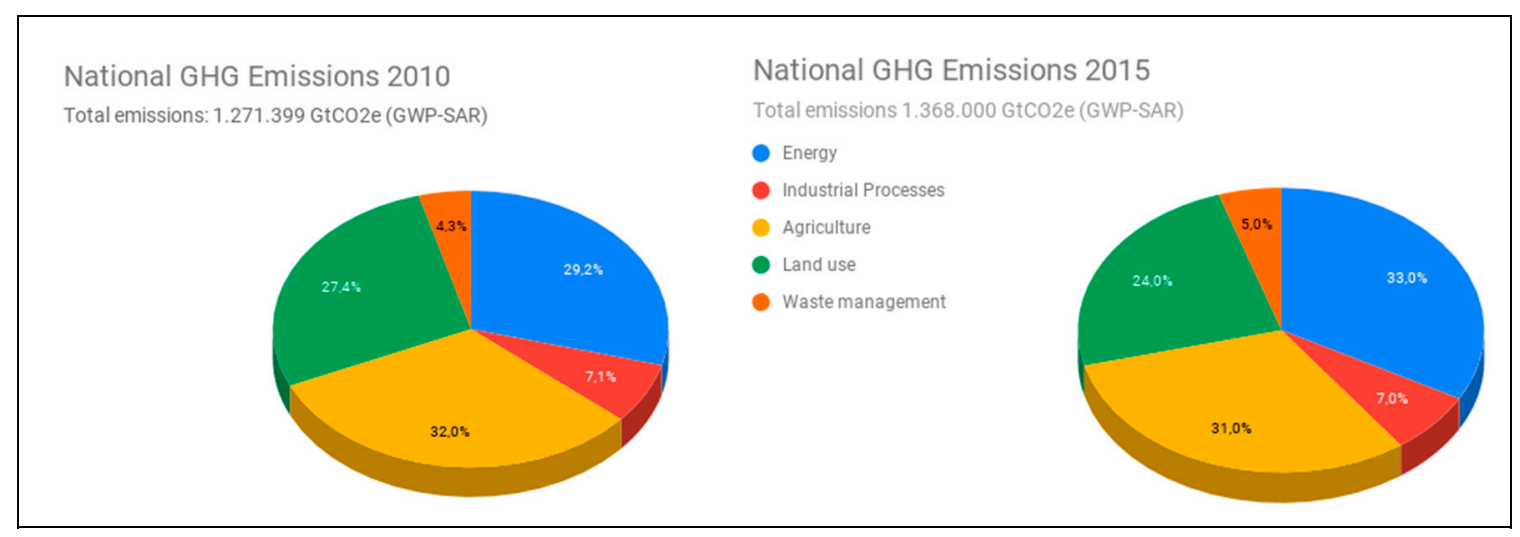

Figure 1. National GHG emissions in 2010 and 2015 [40].

The evolution of the national emissions shows that, between 1990 and 2015, the total emissions line follows the same path as the "Land Use" emissions line, so that the emissions peaks observed in 1995 and 2005 correspond precisely to the "Land Use" high points, observed due to the increase in deforestation in the same periods (Figure 2), especially in the Amazon region (the Amazon, the lungs of the planet, cannot be recovered once it is gone. The August 2019 bush fires blazing in Amazon are part of a larger deforestation crisis, accelerated by President Jair Bolsonaro's policies. According to an article published on 28 August 2019 in New York Times, hundreds of government workers on the front lines of enforcing Brazil's environmental laws signed an open letter warning that their work has been hampered by President Jair Bolsonaro, contributing to a rise in deforestation and the fires sweeping through the Amazon. One of the reasons for such heightened reaction is that the Amazon rainforest fires that have been blazing out of control in Brazil for weeks could have far-reaching effects on environmental and public health-e.g., air quality, weather patterns, loss of biodiversity deforestation, diseases, mental health) [41-43]. 


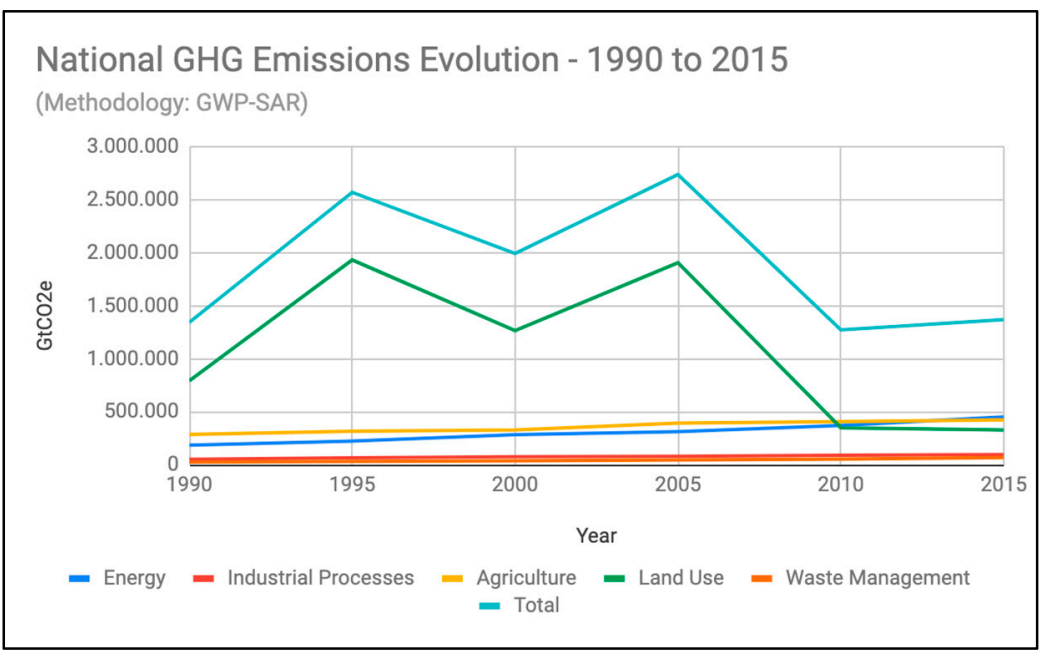

Figure 2. National-level GHG emissions (1990-2015) [40].

The contribution of the "Land Use" and "Agriculture" sectors is comparatively higher than the other sectors', coherently with the fact that, although $85 \%$ of the Brazilian population lives in cities, only $0.63 \%$ of the total 8.156 million $\mathrm{km}^{2}$ of national territory correspond to urban areas [44]. Therefore, at the national level, deforestation control is decisive to the fulfillment of the mitigation targets established on Brazil's NDC. The examination of the inventories of the states of Amazonas, Bahia, Goiânia, Paraná, and São Paulo, where the five cities investigated in this study are located, also corroborates the significant weight of the "Land Use" and "Agriculture Sectors" to the fulfillment of Brazil's NDC mitigation targets (Figure 3).

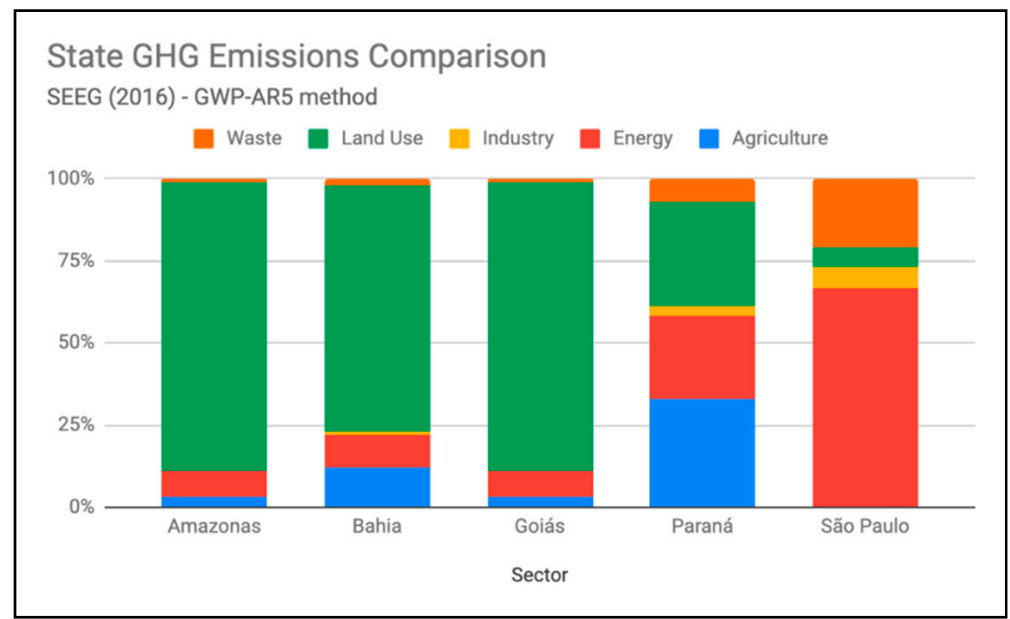

Figure 3. State-level GHG emissions [45].

According to the SEEG GHG inventories (Amazonas and Goiás did not issue official GHG inventories. To fill in this gap, this study has used the SEEG platform emissions estimates, issued by the Climate Observatory according to the IPCC guidelines [46]), the states that are closest to the national emissions framework are Paraná and Goiás. In both, the "Agriculture" sector is responsible for most of the emissions (33\% in Paraná and 54\% in Goiás), followed by the "Land Use" sector (32\% in Paraná and 28\% in Goiás). The "Industry" sector has practically no contribution to emissions in Goiás, while in Paraná it accounts for 3\% of emissions. Coherently, the "Energy" sector accounts for $25 \%$ in Paraná, while in Goiás it corresponds to $13 \%$ of the emissions.

The states closest to the national emissions framework are Paraná and Goiás. In both states, the "Agriculture" sector is responsible for most of the emissions (33\% in Paraná and 54\% in Goiás), 
followed by the "Land Use" sector (32\% in Paraná and 28\% in Goiás). The "Industry" sector has practically no contribution to emissions in Goiás, while in Paraná it accounts for 3\% of emissions. Coherently, the "Energy" sector accounts for 25\% in Paraná, while in Goiás it corresponds to 13\% of the emissions.

In the states of Bahia and Amazonas, the "Land Use" sector is the main responsible for most of the emissions, $75 \%$ in Bahia and $88 \%$ in Amazonas. Nevertheless, there are some significant differences between the two states inventories: in Bahia, the "Agriculture" and "Energy" sectors have higher weight than in Amazonas, accounting respectively for $12 \%$ and $10 \%$ of total emissions, in comparison to only $3 \%$ and $8 \%$ in Amazonas. The "Industry" sector practically does not contribute to the emissions of the state of Amazonas, while in the State of Bahia, industrial emissions represent only $1 \%$ of the total.

In comparison to the national emissions framework, the most discrepant inventory is the state of São Paulo's, the most urbanized and industrialized State in the country. In São Paulo's inventory, the "Energy" sector alone is responsible for 53\% of the emissions. Although the "Agriculture" sector comes in second place, with $20 \%$ of the State's emissions, the other sectors, "Energy", "Industry" and "Waste", more closely related to urban activities, account for $75 \%$ of the total carbon emitted in the State.

About the five investigated cities, it is essential to highlight that all of them have issued legal provisions determining the edition of local emissions inventories. Insofar, Curitiba, Goiânia, Salvador and São Paulo have all issued local emissions inventories, in compliance with municipal regulations. Manaus 2014 Master Plan foresees the implementation of a local vehicle and industrial emissions control program, as the city-located in the heart of the Amazon Forest-has an estimated fleet of 713,000 motor vehicles [47] and about 500 industries installed in the Industrial Zone (Zona Franca), operating mainly in the segments of electronics, two-wheeled vehicles, and chemicals [48]. Regardless, the city has not yet issued an emissions inventory.

A study published by Nobre et al. [49] indicates that the Amazon Forest can undergo irreversible changes due to the continuous loss of biodiversity and deforestation. According to the authors, either a temperature increases above 4 degrees Celsius or deforestation exceeding $40 \%$ of the forest area would be sufficient to lead to the definitive savanization of the region, and in the last 60 years, the temperature in the Amazon has increased by about 1 degree Celsius, with deforestation of about $20 \%$ of the total area of tropical forest. The Amazonas emissions inventory published in the SEEG platform, in turn, indicates that $89 \%$ of total emissions from the state-where the city of Manaus stands-result from changes in land use and 3\% from agricultural activities. Following a downward trend in emissions observed between 2003 and 2009, the survey of the SEEG platform indicates that emissions from the state of Amazonas have been increasing since 2014.

A study published by Liu et al. [50] indicates that pollution from the city of Manaus, more specifically, nitrogen oxides produced by automotive vehicles and industries, significantly interferes with the climate and the ecosystem equilibrium in the Amazon Forest by changing isoprene oxidation, thus interfering with the formation of rains in the region. In view of this situation, the absence of an official emissions inventory for the city of Manaus is hugely worrying, especially considering the significant weight that the Amazon Forest preservation represents for the country's (if not the world's) climate balance as a whole and the fulfillment of the goals assumed by the Brazilian government in its NDC.

As for the other surveyed cities, Curitiba, Salvador, and Goiânia have all issued emissions inventories using the Global Protocol for Community-Scale GHG Emission Inventories (GPC), a method developed specifically for cities by the World Resources Institute (WRI), the C40 Group and ICLEI, based on parameters signed by the Intergovernmental Panel on Climate Change (IPCC). Only the city of São Paulo has applied the IPCC 2006 method (the same used by the Federal Union in the National Inventory). There are no significant incompatibilities between the two methods, thus allowing some comparison between the four local inventories (Figure 4). 


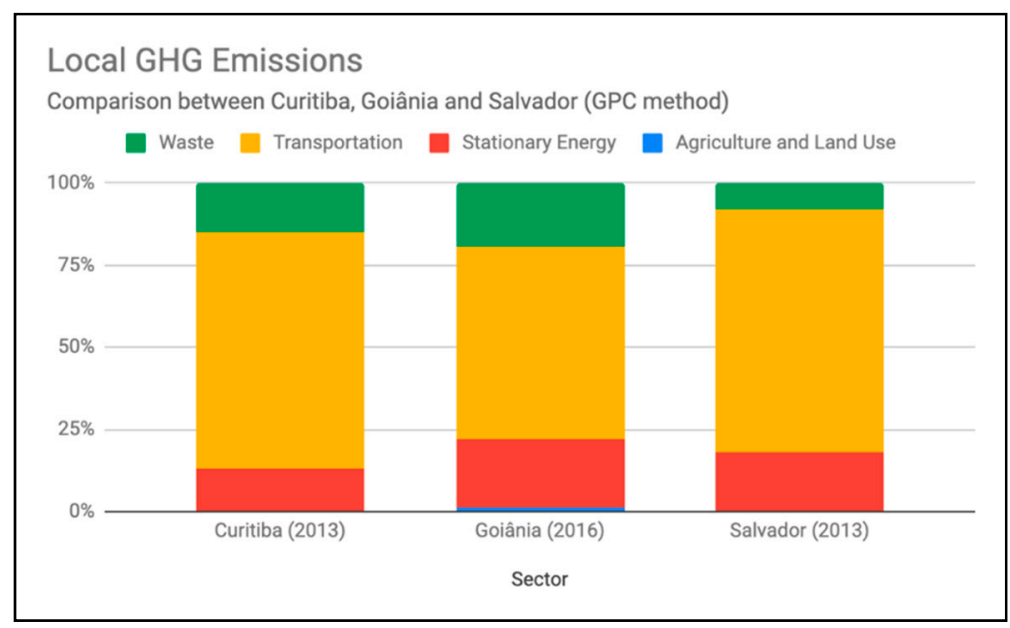

Figure 4. Local-level GHG emissions [51-53].

Considering the three cities that used the GPC method, the sector that occupies the first place in all three inventories is the "Transportation" sector: 78\% of emissions in Salvador, $73 \%$ in Curitiba and $58.47 \%$ in Goiânia. In Salvador and Goiânia, the second place in emissions is occupied by the "Stationary Energy" sector, with 20.58\% in Goiânia and 18\% in Salvador. In Curitiba, the "Stationary Energy" sector occupies the third place, with 12\%, just behind the "Waste" sector, with $15 \%$ of total emissions. In Salvador and Goiânia, the "Waste" sector also has critical participation, occupying the third place, respectively with $8 \%$ and $9.55 \%$ of the emissions. Among the three cities, only the city of Goiânia recorded some contribution to the "Agriculture and Land Use" sector, with $1.4 \%$ of total emissions (Figure 5).

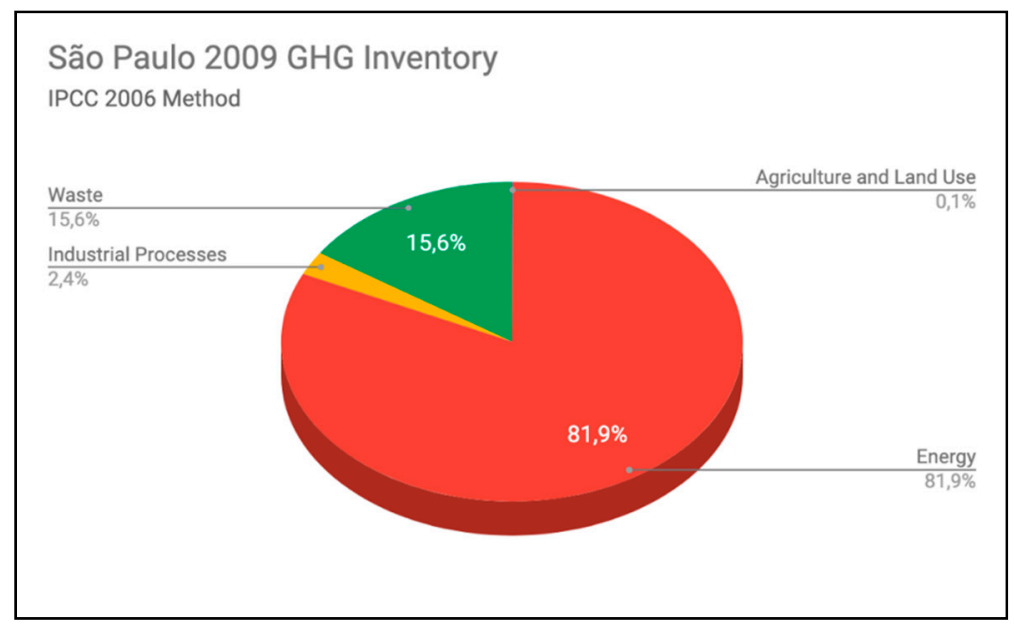

Figure 5. São Paulo's 2009 GHG inventory [54].

São Paulo's emissions inventory, prepared by the IPCC 2006 method, has computed emissions in four sectors: "Agriculture, Forestry and other Soil Use" (AFOLU), "Energy", "Industrial Processes and Product Usage" (IPPU) and "Waste" The first place, accounting for $82 \%$ of the emissions, was the "Energy" sector, covering mostly the fuel combustion emissions (99.7\%) and in a tiny part fugitive energy $(0.3 \%)$. Secondly, the "Waste" sector accounted for $16 \%$ of emissions, followed by the "IPPU" sector, with about $2 \%$ of emissions. The emissions of the "AFOLU" sector were practically irrelevant, which is not surprising considering that most of São Paulo's territory is urban.

Considering that "Energy" emissions are a product of energy consumption in transportation and buildings, it is possible to conclude that the emissions distribution in the city of São Paulo does not differ from the pattern observed in the other three cities, where "Transportation" and "Stationary Energy" 
are responsible for more than $75 \%$ of all three cities' emissions. Another noteworthy observation, concerning decentralized cooperation, lies in the fact that the majority of the official emissions inventories had the technical support of an international actor, as shown in Table 5.

Table 5. State- and city-level GHG inventories * [51-57].

\begin{tabular}{|c|c|c|c|c|c|}
\hline Entity & Edition & Year & Method & Source & Technical Support \\
\hline Manaus & & & & No official emissions inventory & \\
\hline Amazonas & & & & No official emissions inventory & \\
\hline Salvador & 1st & 2013 & GPC & Prefeitura De Salvador (2016) & $\begin{array}{c}\text { ICLEI } \\
\text { WRI Brazil }\end{array}$ \\
\hline Bahia & 1st & 2008 & IPCC 2006 & Governo Do Estado Da Bahia (2010) & None \\
\hline Goiânia & 2nd & 2016 & GPC & Abreu (2017) & $\begin{array}{l}\text { Inter-American } \\
\text { Development Bank }\end{array}$ \\
\hline Goiás & & & & No official emissions inventory & \\
\hline São Paulo & 2nd & 2009 & IPCC 2006 & $\begin{array}{c}\text { Instituto Ekos Brasil, Geoklock Consultoria e } \\
\text { Engenharia Ambiental (2013) }\end{array}$ & World Bank \\
\hline $\begin{array}{l}\text { Estado de } \\
\text { São Paulo }\end{array}$ & 1st & 2008 & IPCC 2006 & Governo Do Estado De São Paulo (2011) & British Embassy \\
\hline Curitiba & $3 \mathrm{rd}$ & 2013 & GPC & Prefeitura De Curitiba (2016) & ICLEI \\
\hline Paraná & 1 st & 2012 & IPCC 2006 & Governo Do Estado Do Paraná (2015) & None \\
\hline
\end{tabular}

* During the study, the City of Goiânia had not officially published the results of its emissions inventory. Request for access to the contents of the inventory based on the right of information, made at the Transparency Portal of the City of Goiânia, was not met.

The comparison between the local, state, and national inventories allows for some additional considerations. Firstly, the main connection point between the national inventory with the state and municipal inventories is the "Waste" sector, which highlights the importance of synergies and coordination between the National, State and Municipal Sanitation and Waste Management Policies in the country.

Secondly, the main connection point between state and municipal inventories is the "Energy" sector, which in cities is strongly related to the high energy consumption by both the "Transport" - mostly, fossil fuels-and the "Stationary Energy" sectors-hydropower and thermoelectric energy. This points out to the need not only to structure state and municipal policies focused on energy efficiency and sustainability but also to coordinate these policies, as well as the resulting plans, programs and projects (according to the 1988 Brazilian Constitution, the Union and the Federated states, not the municipalities, are in charge of all energy sources regulation, production and distribution. Therefore, municipality actions in this field are restricted mostly to energy consumption). This also highlights the strategic importance of Urban Mobility and Public Transport Plans, in their various modalities, including mobility on foot and by bicycle, to emissions control at both the state and the local level.

Finally, the two main connection point between the national and state inventories, respectively, the "Agriculture" and "Land Use" sectors, present very little weight as emission sources in the local inventories. This circumstance, however, does not authorize to discard these sectors as focal points of public policies also at the local level, especially considering the environmental services provided by the environmental protection areas and the preventive role to environmental degradation that can be played by sustainable agriculture in the urban fringes of large cities. The comparison between national, state, and local inventories indicates that cities can contribute to Brazil's NDC more in terms of climate adaptation and resilience than in emissions reduction. Nevertheless, mitigation actions at the local level are also of critical importance, as they contribute to air pollution control, microclimate regulation, and the promotion of public health and quality of life.

\subsection{Local Climate Plans}

Starting in 2009, when the National Climate Change Policy (PNMC) was published, all investigated cities, except for Manaus, have issued their own climate plans. The cities of Curitiba and São Paulo edited their climate plans in the same year of 2009, contemplating Mitigation, Adaptation, and 
Resilience actions. Goiânia, in turn, edited its Sustainable Goiânia Plan in 2011, within the framework of the Inter-American Development Bank's Emerging and Sustainable Cities Platform (IDB). Goiânia's Plan is broader than a strict climate plan but contemplates in-depth climate actions. The city of Salvador, in a similar way, incorporated climate actions into two regulations issued in 2015, one approving the Municipal Program for Sustainable Development and Incentives for Innovation and another approving the Environmental and Sustainable Development Policy of the Municipality. For the city of Manaus, its 2011 Environmental Code has been used in this study as a proxy of "climate plan," since it also contemplates, indirectly, some local climate actions. Table 6 and Figure 6 present the qualitative analysis results of climate plans.

Table 6. Climate action references in local climate plans.

\begin{tabular}{ccccc}
\hline Climate Plan & Adaptation & Cooperation & Mitigation & Resilience \\
\hline Curitiba (2009) & 3 & 1 & 7 & 0 \\
Goiânia (2011) & 63 & 15 & 46 & 26 \\
Manaus (2011) & 35 & 1 & 45 & 0 \\
Salvador (2015) & 28 & 4 & 57 & 2 \\
São Paulo (2009) & 23 & 1 & 99 & 7 \\
Total & 152 & 22 & 254 & 35 \\
\hline
\end{tabular}

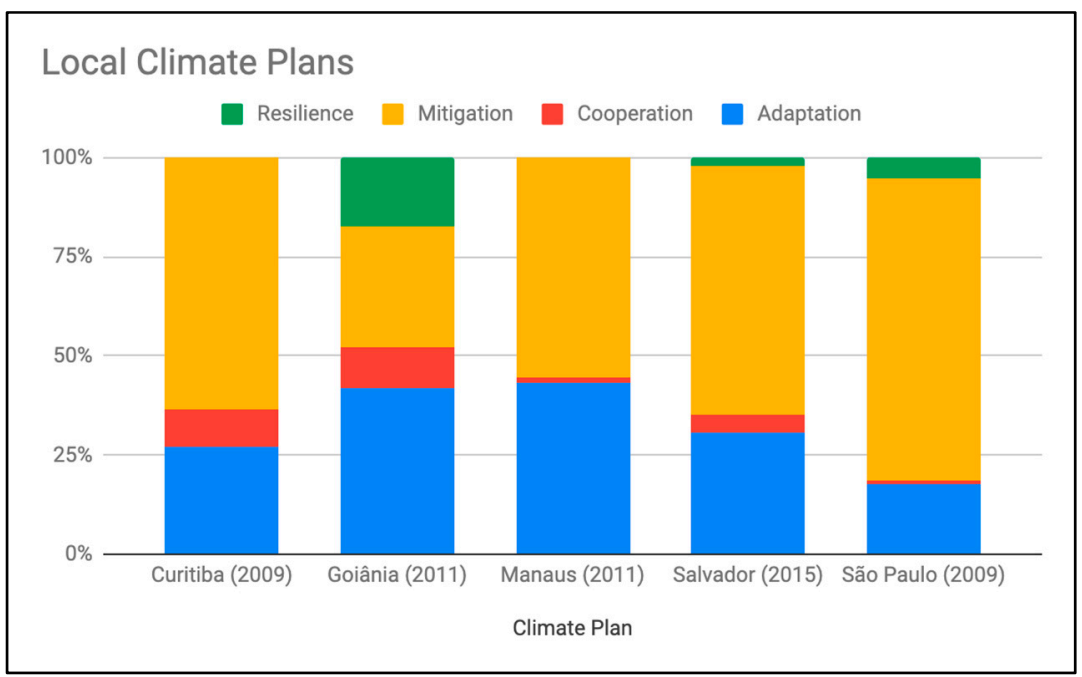

Figure 6. Climate action references in local climate plans.

In four of the five local climate plans, except Goiania's, Mitigation was the most referenced climate axis, what is a consequence of the investigated cities' concern with the consumption of fossil fuels and sustainable waste management. In the case of São Paulo's, more than $75 \%$ of the references relate to Mitigation.

This finding is consistent with the fact that combating air pollution, mainly particulate matter produced by motor vehicles, is a critical challenge for the city of São Paulo [58]. According to Saldiva [59], the reduction of air pollution in the city of São Paulo to the levels recommended by the World Health Organization (WHO) could bring about an increase in the life expectancy of the population of about three years. Thus, alternatives to fossil fuels in urban mobility is a crucial issue in São Paulo's climate strategy. Besides, in these four investigated cities adaptation was the second most mentioned climate action axis. Goiânia's Climate Plan presented a higher number of references to Resilience in comparison to the other cities' Climate Plans. In all cities, the cooperation axis was the least mentioned. Considering the total number of references observed in the five Climate Plans, Mitigation obtained $54 \%$ of the references, Adaptation, $32.8 \%$, followed by references to Resilience, with $7.6 \%$, and Cooperation, with only $4.8 \%$ (Figure 7 ). 


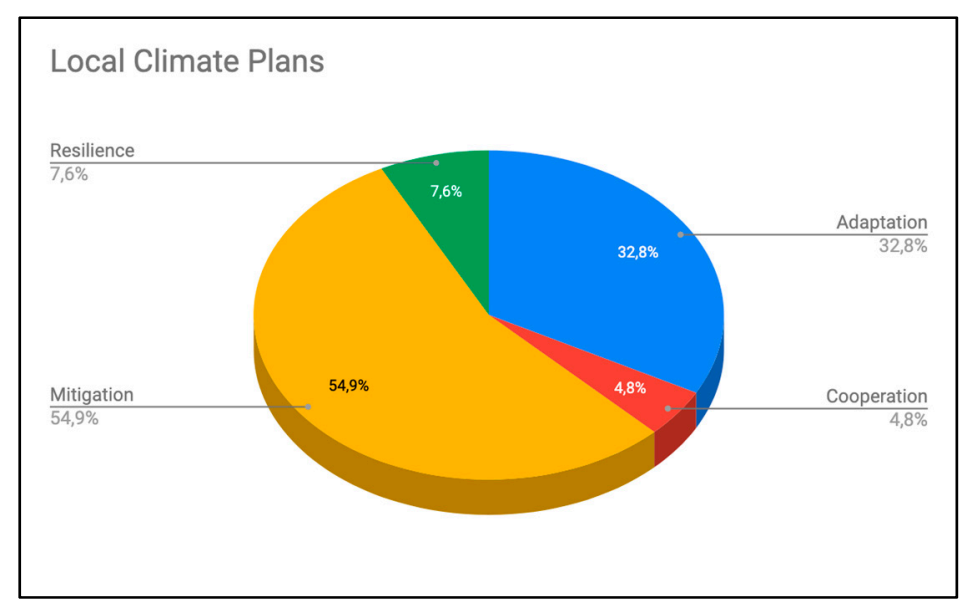

Figure 7. Climate action references in local climate plans.

\subsection{City Master Plans}

In Brazil, according to the 1988 Brazilian Constitution [60], whereas environmental protection is a competence shared by all the federated entities, urban planning and urban management are, mostly, local or municipal issues. Municipalities with a minimum population of 20,000 inhabitants are hence obligated to edit their Master Plans, not only to set their essential territorial planning guidelines but also to coordinate and integrate land use, environmental protection and sectoral policies regulations at the local level. Hence, Master Plans should present at least some reference to climate action amongst their provisions. All the five investigated cities have issued Master Plans following the guidelines and minimum requirements set by the 2001 Statute of the City, Brazil's national law on urban planning and management (Table 7).

Table 7. Climate action references in master plans.

\begin{tabular}{ccccc}
\hline Master Plan & Adaptation & Cooperation & Mitigation & Resilience \\
\hline Curitiba (2015) & 44 & 1 & 22 & 9 \\
Goiânia (2007) & 59 & 0 & 10 & 7 \\
Manaus (2014) & 42 & 0 & 3 & 0 \\
Salvador (2016) & 143 & 0 & 63 & 45 \\
São Paulo (2014) & 253 & 0 & 62 & 42 \\
Total & 541 & 1 & 160 & 253 \\
\hline
\end{tabular}

All of the investigated Master Plans contain references to Adaptation, Mitigation, and Resilience actions, except for Manaus, which did not show results for Resilience actions. Furthermore, only Curitiba's Master Plan has presented one reference to decentralized cooperation actions. All five Master Plans have shown a higher number of references to Adaptation actions, in the first place, and to Mitigation actions, in the second place. Taking the sum of all the Master Plans' references to climate action, the most mentioned axis was Adaptation, with $67.2 \% \%$ of the references, followed by Mitigation, with $19.9 \%$, Resilience, with $12.8 \%$ and Cooperation, with $0.1 \%$ (Figure 8 ). 


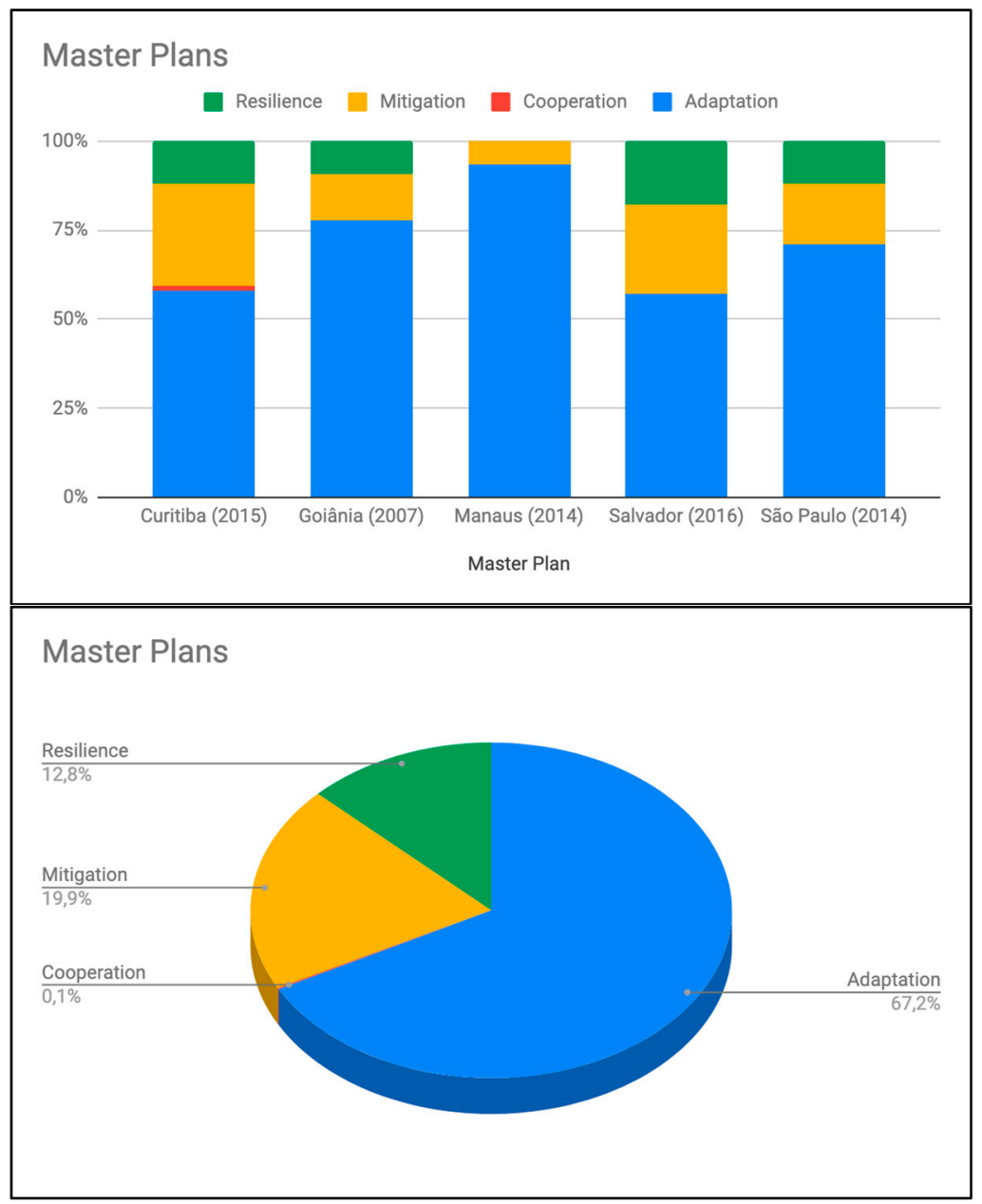

Figure 8. Climate action references in master plans.

\subsection{Land Use Regulations}

For the sake of analysis, all regulations about zoning, land use, parceling and development, such as zoning laws, land use laws and building codes, have been gathered under the unique topic "land use regulations" (Table 8).

Table 8. Climate action references in city land use regulations.

\begin{tabular}{ccccc}
\hline City & Adaptation & Cooperation & Mitigation & Resilience \\
\hline Curitiba & 137 & 2 & 23 & 31 \\
Goiânia & 358 & 13 & 61 & 552 \\
Manaus & 22 & 0 & 7 & 4 \\
Salvador & 70 & 0 & 23 & 10 \\
São Paulo & 64 & 0 & 25 & 8 \\
Total & 651 & 15 & 139 & 605 \\
\hline
\end{tabular}

In Manaus, Salvador and São Paulo, the most referenced climate action axis was, firstly, Adaptation, followed by Mitigation and Resilience. The cities of Goiânia and Curitiba were the only ones to present references to decentralized cooperation actions in their land use regulations. In the city of Goiânia, the most mentioned axis was Resilience, followed by Adaptation and Mitigation. In the city of Curitiba, the most mentioned axis was Adaptation, followed by Resilience and Mitigation (Figure 9). Considering the overall sum of references, the Adaptation axis was the most mentioned, with $46.2 \%$, followed by Resilience, with 42.9\%, Mitigation, with 9.9\% and Cooperation with only $1.1 \%$ (Figure 9). 

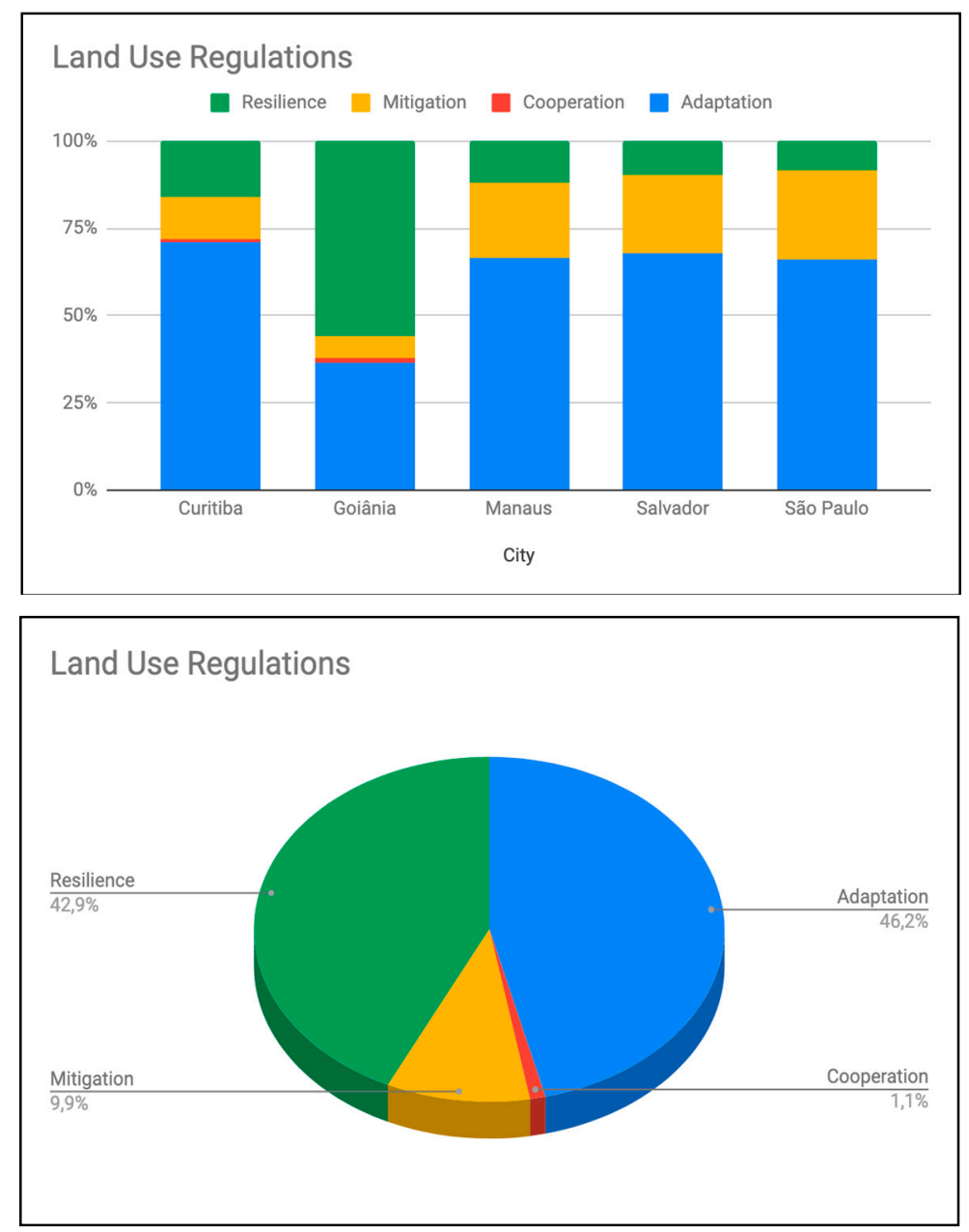

Figure 9. Climate action references in city land use regulations.

\subsection{Sectoral Plans}

According to the 1988 Brazilian Constitution, municipalities have the powers to provide for all essential public services at the local level, following both national and state directives. Thus, the data survey involved the following public policies: housing, mobility, sanitation, solid waste, urban drainage, disasters, and health. The goal was to detect the incorporation of local climate actions also in these fields. According to the Brazilian 1988 Constitution and the 2001 Statute of the City, local public policies must be coordinated and integrated, following the city's Master Plan guidelines.

According to national regulations, the edition of local plans on Sanitation, Waste Management, and Urban Mobility is mandatory to Municipalities [61-63]. Drainage plans are not mandatory; however, due to extreme weather events, an increasing number of cities have recently issued, if not proper plans, at least specific regulations on urban drainage and rainwater management. Concerning housing, even though local Housing Plans are as well not mandatory, in order to access National Social Housing Fund resources municipalities must edit Social Housing Plans, focused on housing provision for low-income families [64].

Regarding disasters, the National System of Civil Protection and Defense, regulated by a 2012 National Law [65], expressly integrates the Municipalities as Members, with a set of local attributions, amongst them the powers to incorporate protection and civil defense actions in municipal planning, to map disaster risk areas and to declare emergency situations and public calamity at the local level. Thus, it is incumbent to the Municipalities, if not to draft typical local disaster prevention and mitigation plans, at least to structure their respective Civil Defense at the local level. 
Lastly, concerning Public Health, the 1988 Brazilian Constitution has expressly granted Municipalities the powers to provide, with the technical and financial cooperation of the union and the states, health care services for the population at the local level. The Municipalities are thus included in the Unified Health System (SUS), and must, therefore prepare and periodically update their respective Local Health Plans [66]. Tables 9-13 and Figures 10-14 presents the analysis results that are obtained per investigated city.

Table 9. Climate action references in Curitiba's sectoral plans.

\begin{tabular}{ccccc}
\hline CURITIBA & Adaptation & Cooperation & Mitigation & Resilience \\
\hline Disasters & 9 & 0 & 0 & 24 \\
Drainage & 531 & 1 & 35 & 179 \\
Health & 2 & 0 & 0 & 2 \\
Housing & 112 & 10 & 23 & 4 \\
Mobility & 1 & 0 & 2 & 0 \\
Sanitation & 1318 & 18 & 37 & 64 \\
Waste & 59 & 4 & 37 & 5 \\
\hline
\end{tabular}

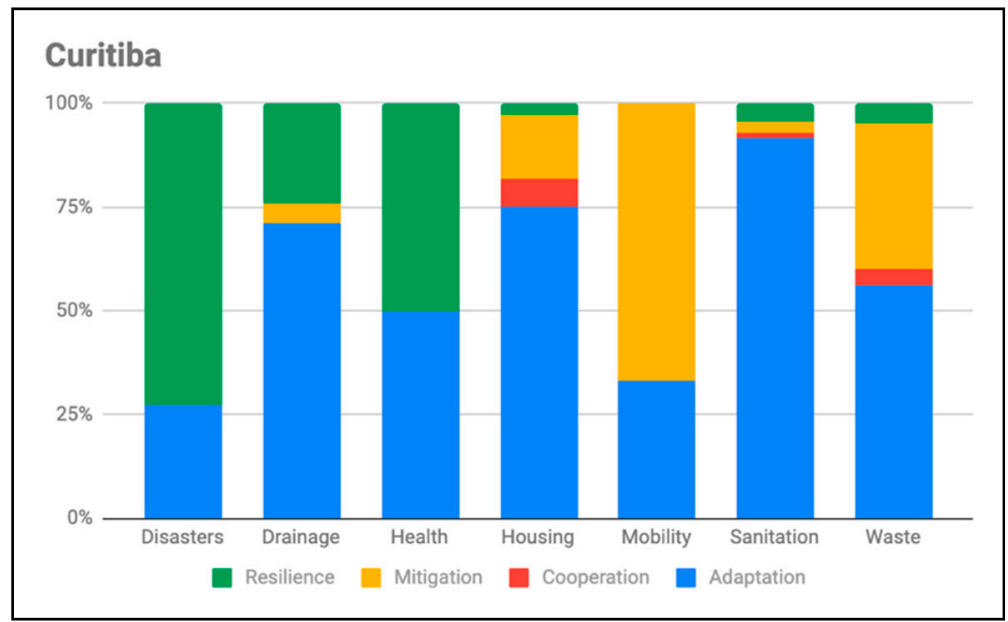

Figure 10. Climate action references in Curitiba's sectoral plans.

Table 10. Climate action references in Goiânia's sectoral plans.

\begin{tabular}{ccccc}
\hline GOIÂNIA & Adaptation & Cooperation & Mitigation & Resilience \\
\hline Disasters & 20 & 0 & 0 & 2 \\
Drainage & 57 & 0 & 3 & 4 \\
Health & 44 & 0 & 1 & 6 \\
Housing & 0 & 0 & 0 & 0 \\
Mobility & 0 & 0 & 0 & 0 \\
Sanitation & 0 & 0 & 0 & 0 \\
Waste & 76 & 8 & 86 & 23 \\
\hline
\end{tabular}




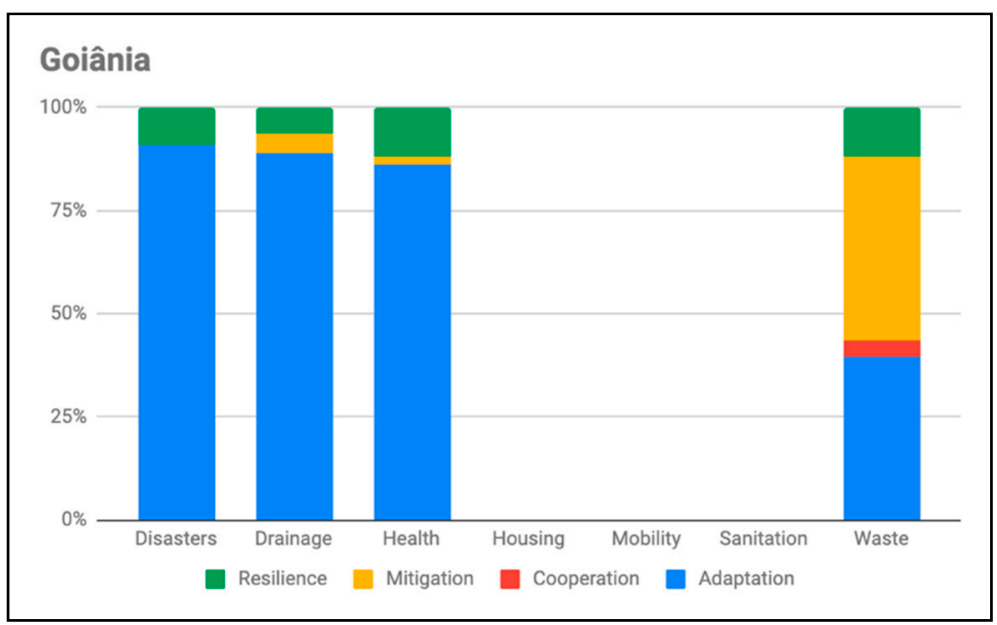

Figure 11. Climate action references in Goiânia's sectoral plans.

Table 11. Climate action references in Manaus' sectoral plans.

\begin{tabular}{ccccc}
\hline MANAUS & Adaptation & Cooperation & Mitigation & Resilience \\
\hline Disasters & 39 & 6 & 0 & 2 \\
Drainage & 0 & 0 & 0 & 0 \\
Health & 39 & 6 & 0 & 2 \\
Housing & 0 & 0 & 0 & 0 \\
Mobility & 16 & 0 & 131 & 107 \\
Sanitation & 553 & 3 & 30 & 12 \\
Waste & 40 & 0 & 117 & 3 \\
\hline
\end{tabular}

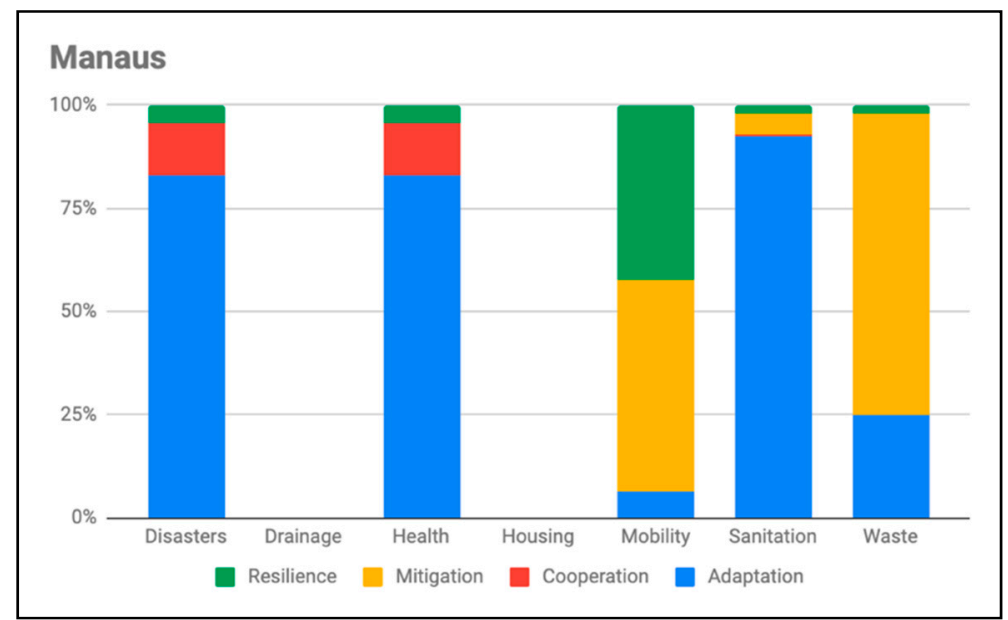

Figure 12. Climate action references in Manaus' sectoral plans.

Table 12. Climate action references in Salvador's sectoral plans.

\begin{tabular}{ccccc}
\hline SALVADOR & Adaptation & Cooperation & Mitigation & Resilience \\
\hline Disasters & 99 & 0 & 2 & 118 \\
Drainage & 0 & 0 & 0 & 0 \\
Health & 195 & 13 & 6 & 52 \\
Housing & 0 & 0 & 0 & 0 \\
Mobility & 36 & 9 & 62 & 11 \\
Sanitation & 18 & 0 & 1 & 0 \\
Waste & 1 & 0 & 0 & 0 \\
\hline
\end{tabular}




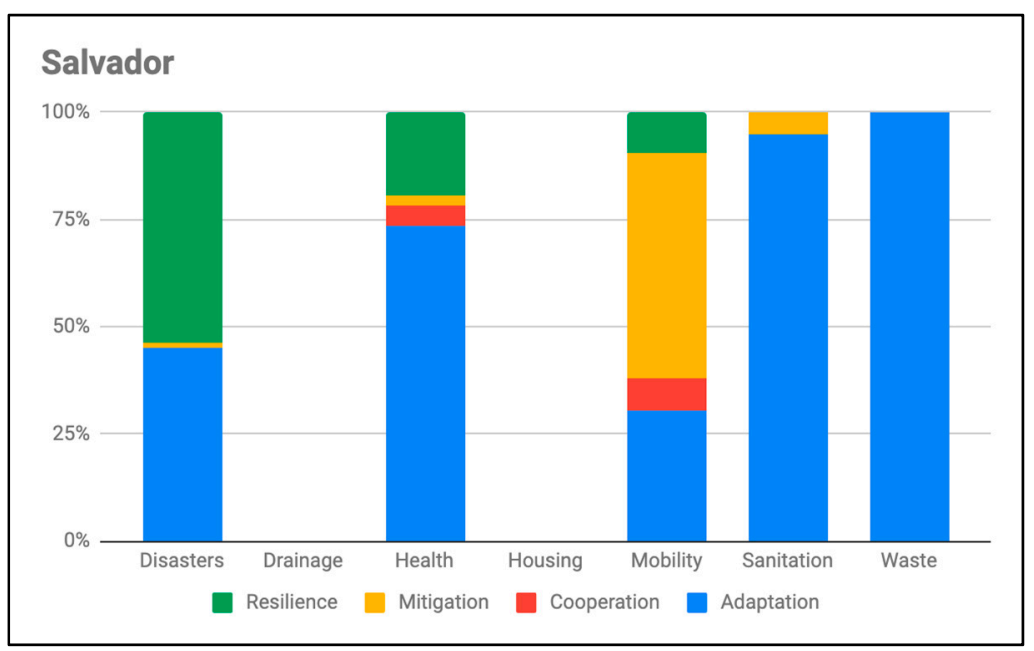

Figure 13. Climate action references in Salvador's sectoral plans.

Table 13. Climate action references in São Paulo's sectoral plans.

\begin{tabular}{ccccc}
\hline SÃO PAULO & Adaptation & Cooperation & Mitigation & Resilience \\
\hline Disasters & 25 & 0 & 0 & 41 \\
Drainage & 1666 & 4 & 202 & 425 \\
Health & 271 & 0 & 3 & 0 \\
Housing & 103 & 0 & 8 & 12 \\
Mobility & 43 & 7 & 228 & 4 \\
Sanitation & 721 & 10 & 202 & 93 \\
Waste & 84 & 6 & 153 & 48 \\
\hline
\end{tabular}

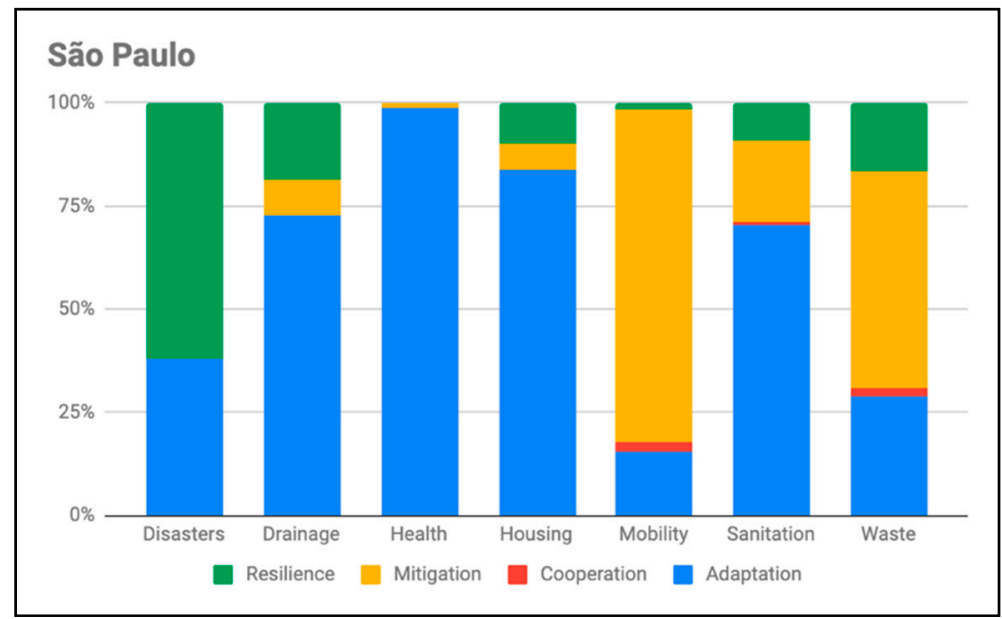

Figure 14. Climate action references in São Paulo's sectoral plans.

Among the five investigated cities, only São Paulo and Curitiba presented references to climate actions in all sectoral policies: Disasters, Drainage, Health, Housing, Mobility, Sanitation, and Waste management. Goiânia did not present references to climate actions in Housing, Mobility, and Sanitation. Manaus and Salvador, in turn, did not present references to climate actions in Drainage and Housing.

Firstly, concerning Disasters Management, the most referenced climate action axis in the cities of Curitiba, Salvador-the latter, the Brazilian city with the most significant number of inhabitants in the risk area [67] —and São Paulo was Resilience, followed by Adaptation. In Goiânia and the axis most commonly referred to was Adaptation. Unlike the other investigated cities, the Municipality of Manaus dealt with the prevention and remediation of disasters in its Municipal Health Plan and not, as expected, in civil defense regulations. 
In what concerns Drainage, the most referenced climate action axis in the cities of Curitiba, Goiânia and São Paulo was Adaptation, followed by Resilience, in second, and Mitigation, in third place. Only the cities of São Paulo and Curitiba presented references to cooperation actions in urban drainage. Manaus and Salvador did not present any results in this field, as the document survey did not locate any documents specifically dedicated to urban drainage for both cities.

Only São Paulo and Curitiba presented references to climate action in Housing policy documents. Adaptation was the axis with the highest number of references, followed, in the case of São Paulo, by Resilience, in the second place, and Mitigation, in the third place; in the case of Curitiba, Mitigation occupied the second place, followed respectively by Cooperation, in third, and Resilience, in fourth.

In the field of Urban Mobility, except for Goiânia, all the investigated cities presented a higher number of references to Mitigation, followed by Adaptation in São Paulo, Salvador and Curitiba, and Resilience in Manaus. Only São Paulo and Salvador presented references to the Cooperation axis. The city of Goiânia did not present any references to climate action in its Municipal Urban Mobility Plan, still under development.

Concerning Sanitation, the axis of climate action with the most significant number of references in the cities of São Paulo, Salvador, Manaus, and Curitiba, was Adaptation. Mitigation was the second most mentioned axis in São Paulo, Salvador, and Manaus; in Curitiba, it was the Resilience axis. There are references to Cooperation only in the Sanitation Plans of Curitiba and São Paulo. The Municipal Sanitation Plan of Goiânia (in preparation) did not present references to any climate action axis.

For Waste Management, Adaptation was the most referenced axis in both Curitiba and Salvador Waste Management Plans. In the cities of São Paulo, Manaus and Goiânia, Mitigation was the most referenced axis, followed by Adaptation and Resilience. Only the cities of Curitiba, Goiânia and São Paulo presented references to the Cooperation axis in their Local Waste Management Plans.

Finally, concerning Public Health, Adaptation was the most referenced climate action axis in all five Local Health Plans, followed by Mitigation, in São Paulo, and by Resilience, in Curitiba, Goiânia, and Salvador. References to Coordination actions were found only in the Health Plans of Salvador and Manaus.

A word search focused on the Municipal Public Health Plans pointed out that only Salvador's contains references to the expression "climate change", detected in two contexts: the articulation of health and climate agendas and the prevention of arboviruses such as yellow fever. Furthermore, based on the assumption that health promotion is a necessary component of sustainable urban development, another specific Word Search was carried out, aimed at locating references to "health" in all the investigated Local Climate Plans, Master Plans, Land Use Regulations and other Sectoral Plans (Table 14). The results confirm the initial hypothesis that "health" is an integral dimension of urban planning in the five investigated cities, including concerning climate change issues.

Table 14. References to health in city sectoral plans.

\begin{tabular}{cccccc}
\hline Documents & Curitiba & Goiania & Manaus & Salvador & São Paulo \\
\hline Climate Plan & 0 & 5 & 23 & 34 & 8 \\
Master Plan & 43 & 46 & 9 & 69 & 33 \\
Land Use Regulations & 62 & 37 & 7 & 11 & 25 \\
Disasters & 1 & 0 & $948^{*}$ & 21 & 3 \\
Drainage & 6 & 0 & 0 & 0 & 31 \\
Housing & 84 & 1 & 0 & 0 & 6 \\
Sanitation & 279 & 0 & 18 & 0 & 343 \\
Waste & 110 & 124 & 82 & 0 & 224
\end{tabular}

* Disaster management is a content of the Manaus Municipal Public Health Plan, hence returns the highest number of results.

Figure 15 figure illustrates that there are references to health in the Master Plans and the Land Use Regulations of all the investigated cities. All Local Climate Plans, except Curitiba's, also make references 
to health. Finally, there are, references to health in most of the sectoral plans of the investigated cities, especially sanitation and waste management plans. Overall results are sorted by sectoral policy and climate action axis presented, in turn, the following findings (Table 15).

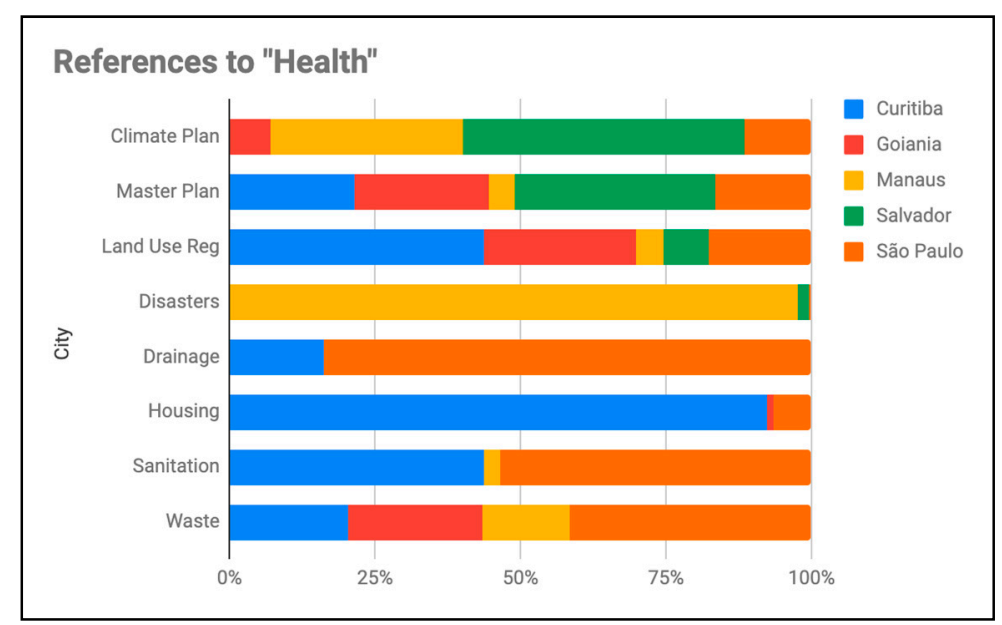

Figure 15. References to health in city sectoral plans.

Table 15. Climate action references in sectoral policies.

\begin{tabular}{ccccc}
\hline Sectoral Policy & Adaptation & Cooperation & Mitigation & Resilience \\
\hline Disasters & 192 & 6 & 2 & 187 \\
Drainage & 2254 & 5 & 24 & 608 \\
Housing & 215 & 10 & 31 & 16 \\
Mobility & 96 & 16 & 423 & 122 \\
Sanitation & 1437 & 31 & 270 & 169 \\
Public Health & 561 & 19 & 10 & 62 \\
Waste & 260 & 18 & 394 & 79 \\
Total & 5015 & 105 & 1370 & 1243 \\
\hline
\end{tabular}

Adaptation was the most referenced axis in the majority of the sectoral policies documents: Disasters, Drainage, Housing, Sanitation, and Public Health. Mobility and Waste management Document presented more references to Mitigations. Resilience was the second most referred axis in Drainage, Disaster, and Mobility. Considering the total number of references, the Adaptation axis was the most referenced, with $71.2 \%$, followed by Resilience, with $14.3 \%$, Mitigation, with $13.3 \%$ and Cooperation, with $1.2 \%$ (Figure 16). 


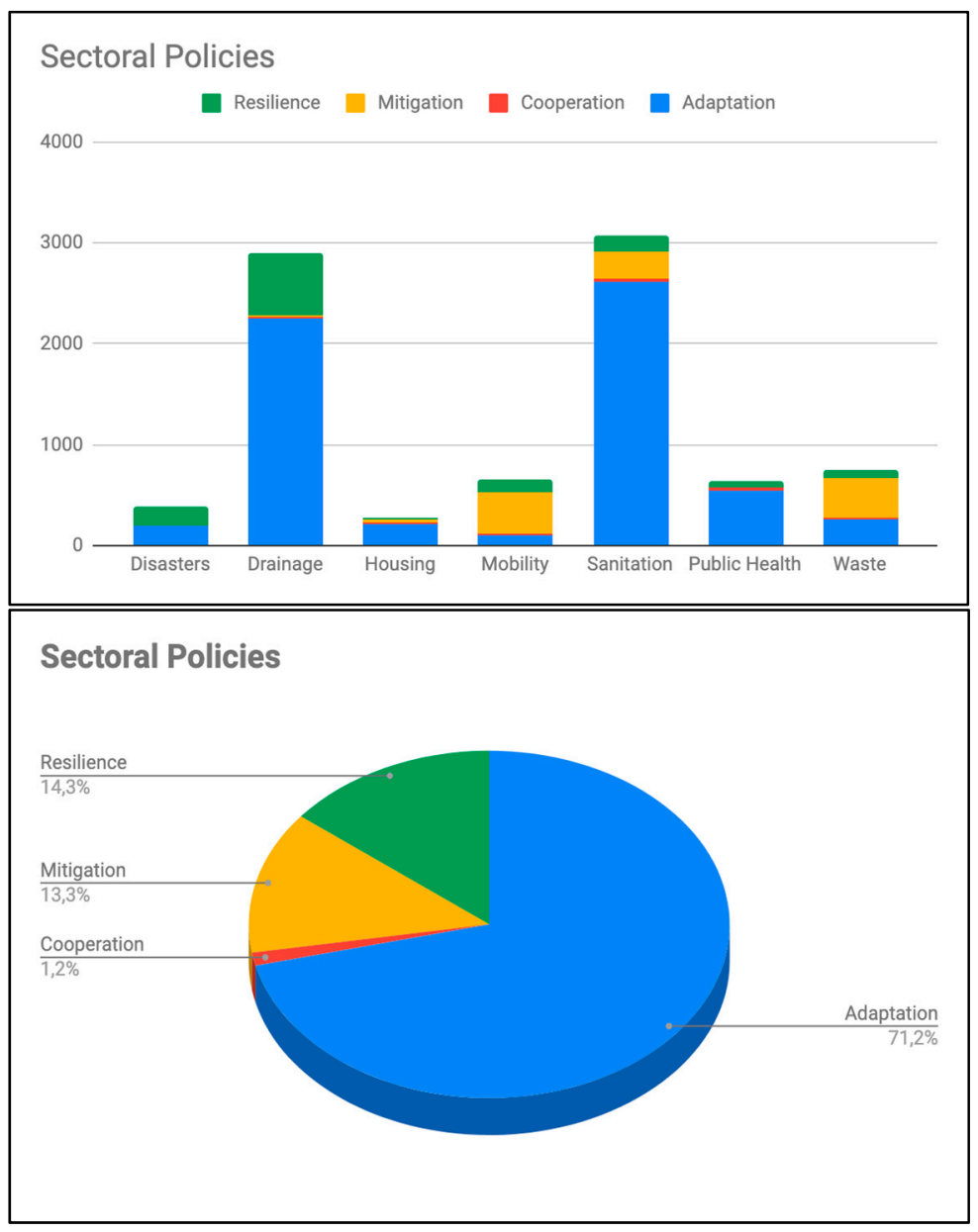

Figure 16. Climate action references in sectoral policies.

\section{Discussion}

\subsection{Institutional Frameworks and Climate Action in Brazil}

The 1992 United Nations Conference on Environment and Development (UNCED) fostered the edition of the 1992 United Nations Framework Convention on Climate Change (UNFCCC). As its hosts, Brazil has been for some time, one of the Global South main protagonists in climate change negotiations (the situation has changed dramatically with the election of Brazilian President Jair Bolsonaro in October 2018, a far-right open climate skeptic anti-environmentalist politician. Just before taking on office, the new Presidential Cabinet withdrew Brazil's proposal to host the 25th UNFCCC Conference of Parties (COP 25), to be held in December 2019, and since the very first days of the federal mandate, the appointed Minister of Environment, Ricardo Salles, has been making significant cuts on climate programs and initiatives at the national level. In this context, it is essential to highlight that this paper portrays the institutional framework before President Bolsonaro's inauguration, as comprised in the years of 2017 and 2018. In other words, this study discloses a much more positive standing of Brazil in the climate action than what it is actually today) [30]. Nevertheless, the country has only issued a national climate change policy (PNMC) long after the edition of the 1997 Kyoto Protocol, through the approval of a national law in the year of 2009 [68].

In resonance to the Brazilian Federation legal framework, PNMC expressly contemplates amongst its primary goals the promotion of climate adaptation in all levels—national, regional and local—with the participation and collaboration of all implicated stakeholders. Furthermore, all measures taken at the national level must consider and integrate regional and local actions taken by both public and private entities. PNMC also fosters integration between mitigation and adaptation strategies in all 
federative levels, as well as the engagement of all sectors in the implementation of climate policies, plans, programs, and strategic actions.

Under the 1992 UNFCCC, all states signatory to the 2015 Paris Agreement, regardless of their level of economic development, are obliged to comply with the voluntary commitments embodied in their respective NDC. The NDC mechanism was formulated to effectively engage and commit the UNFCCC member states in the pursuit of the 1.5-degree Celsius target. As a result, it can be affirmed that unlike its predecessor-the 1997 Kyoto Protocol—the Paris Agreement is a legally binding agreement [69].

Following its adherence to the Paris Agreement in September 2016, Brazil's national government duly presented its NDC in 2017, with an emissions reduction target of $37 \%$ below the national emissions average until 2025, and a complementary reduction target of 43\% below 2005 levels until 2030 [20], as well as adaptation measures, all based in the 2016 National Adaptation Plan (PNA) [70]. The 2016 PNA main objectives are to promote risk management and reduction at the national level; to guide the expansion and dissemination of knowledge; to foster cooperation and coordination between the public and private sectors, and to identify and to propose adaptation measures. PNA covers a total of 11 strategic sectors: industry, vulnerable social groups, water, infrastructure, coastal zone, food security, agriculture, biodiversity, cities, health, and disaster prevention, and mitigation.

With regard specifically to the linkages between climate change and public health, the Ministry of Health has edited a Sectoral Health Plan for Mitigation and Adaptation to Climate Change in 2013 [71]. This plan's main objective is to organize the public health services response to climate change in terms of both adaptation and mitigation, through four lines of action: health surveillance, health care, health promotion and education, and health research, each pointing out objectives, indicators, expected results and the governmental agency responsible for each action.

The 2013 Sectoral Health Plan appoints the critical challenges of climate change to public health. Firstly, deaths and morbidities due to disasters and communicable diseases such as dengue fever, yellow fever, Zika virus, and leishmaniosis. Secondly, deaths and morbidities due to non-communicable diseases such as cardiovascular and respiratory diseases, linked to air pollution, and also skin cancer, linked to the destruction of ozone layer. The plan highlights the vital role to be played by local authorities regarding resilience, adaptation, and mitigation. In terms of resilience, the plan focuses on natural disasters, to be caused by extreme weather events. In terms of adaptation, the plan points local actions in the fields of housing, sanitation, and green areas. Lastly, for mitigation, the plan highlights the importance of active urban mobility in order to target air pollution and promote physical activity.

The 1988 Brazilian Constitution expressly grants municipalities the powers to act on environmental preservation as well as on urban planning. Thus, climate actions are expected to permeate both environmental and urban policies at the local level, either in local climate plans or in local regulations in general, such as Master Plans, Land Use Regulations, and Sectoral Policy Plans.

Nonetheless, at the national level, the topics "climate change", "sustainable urban development", "public health" and "disasters management" are under the responsibility of separate Federal bodies, respectively, Ministry of Environment, Ministry of Cities (the Ministry of Cities was terminated by President Jair Bolsonaro in January 2019-its former attributions have been partially absorbed by the Ministry of Regional Development, Ministry of Health, and Ministry of Science, Technology, Innovation and Communications). There is roughly no common agenda specifically focused on urban climate policy, which results in the lack of consistent monitoring of the local policies, plans, programs and climate actions currently conducted by the Brazilian municipalities [72,73].

\subsection{Local Emissions Inventories and Climate Plans}

Firstly, four of the five surveyed cities have published GHG emissions inventories in the context of decentralized cooperation agreements: Curitiba, with the support of ICLEI; Goiannia, with support from the Inter-American Development Bank; Salvador, with support from ICLEI and WRI Brazil and São Paulo, with support from the World Bank. All four investigated cities, having compiled GHGs inventories, have subsequently edited their respective Local Climate Plans. Thus, preparation of GHGs 
inventories seems to be, in fact, a necessary preparatory step for climate plans. Moreover, all the investigated Local Climate Plans came to light as of 2009, year of the edition of the National Policy on Climate Change (PNMC).

Manaus was the only city not to assemble an emissions inventory or a specific Climate Plan. Nevertheless, its 2011 Environmental Code contains references to Adaptation and Mitigation actions, allowing its use as a proxy for a climate plan in this investigation. Of the five cities investigated, only Curitiba edited documents specifically dedicated to Adaptation and Resilience, following the internationally recommended standards. Also, it has contemplated climate actions in its Master Plan, Land Use Regulation, and all Sectoral Plans. Hence, this city is at the forefront of climate action, ahead of the other surveyed cities. Decentralized cooperation and the edition of the PNMC can be pointed out as the two main engines for the structuring of local climate actions, considering, firstly, the participation of international actors on the local emissions inventories and climate plans; and, secondly, the adherence of the investigated cities to national guidelines-PNMC included-while structuring their local public policies.

\subsection{Contribution to Greenhouse Gas Emission Reduction}

The PNMC emphasizes city's role in climate Adaptation, first of all, and in urban Resilience, but not so much in climate Mitigation, what is consistent with the data contemplated in the National GHG inventory. National emissions estimates show that the contribution of the most relevant sectors to urban activities—e.g., Waste and Energy - is relatively low when compared to the Agriculture and Land Use sectors. In line with the PNMC, Adaptation was the climate action axis with the most significant number of references in the Master Plans, Land Use Regulations and Sectoral Plan. Mitigation, however, had the highest number of references in the local Climate Plans, Urban Mobility and Waste Management, what enhances the cities concerns with fossil fuels consumption and sustainable management of waste residues and effluents.

Furthermore, in line with the PNMC, Resilience was the second most referenced climate action axis in Land Use Regulations, Disasters Management, Drainage, Health and Urban Mobility Plans, demonstrating that the investigated cities have made efforts to incorporate the coping of shock and stress factors into their planning and management processes. Decentralized cooperation was overall the least referenced climate action. Nonetheless, it was possible to detect references to cooperation actions in the compiled documents from all investigated cities, confirming their engagement with the international community regarding climate change issues.

\subsection{Climate Action in Public Health and Disasters Management}

Qualitative analysis results reported in this paper revealed that health promotion effectively integrates Local Climate Plans, Master Plans, Land Use Regulations and Sectoral Plans of the five investigated cities, with a more significant number of references to Health promotion actions in Sanitation and Waste Management Plans, what reinforces the critical connection between Sanitation and Public Health policies in urban areas. Municipal Public Health Plans and the Disaster Management regulations of the five surveyed cities do incorporate climate action, mainly in the Adaptation axis, but not so much in Resilience. The analyzed Local Public Health and Disaster Management Policies did present some connections, but not, as it would be desirable, effective coordination of projects and actions in the investigated cities. Municipality of Manaus, at this point, provided innovative treatment to the issue, incorporating Disaster management into the Municipal Public Health Plan.

\subsection{Limitations of the Study}

This study encountered a number of limitations. The following issues should be considered when interpreting the findings of this study: (a) The data collection process, even undertaken thoroughly, may have unintentionally omitted some policy documents-e.g., the ones that are approved after the data is collected; (b) The study does not factor in the maturity of the policy-e.g., whether just released 
or in place for quite some time; (c) The study does not factor in whether the policy is implemented; and if so how effective results it generated; (d) The content analysis technique, even conducted with the aid of a software, may contain unconscious bias-e.g., selection of keywords and nodes; (e) The results of the content analysis, even reviewed with utmost care, may have interpreted differently-e.g., due to unconscious bias of the researchers; (f) The findings could not be crosschecked with any other empirical research, since this is a pioneering study; $(\mathrm{g})$ The study portrays the institutional framework before President Bolsonaro's inauguration, as comprised in the years of 2017 and 2018; meaning it discloses a much more positive standing of Brazil in the climate action than what it is actually today, and; (h) The study did not investigate the preparedness of the planning and emergency frameworks in combatting major climate-related catastrophes, such as the recent Amazon rainforest fires (Figure 17). In our prospective studies, we will overcome these limitations.

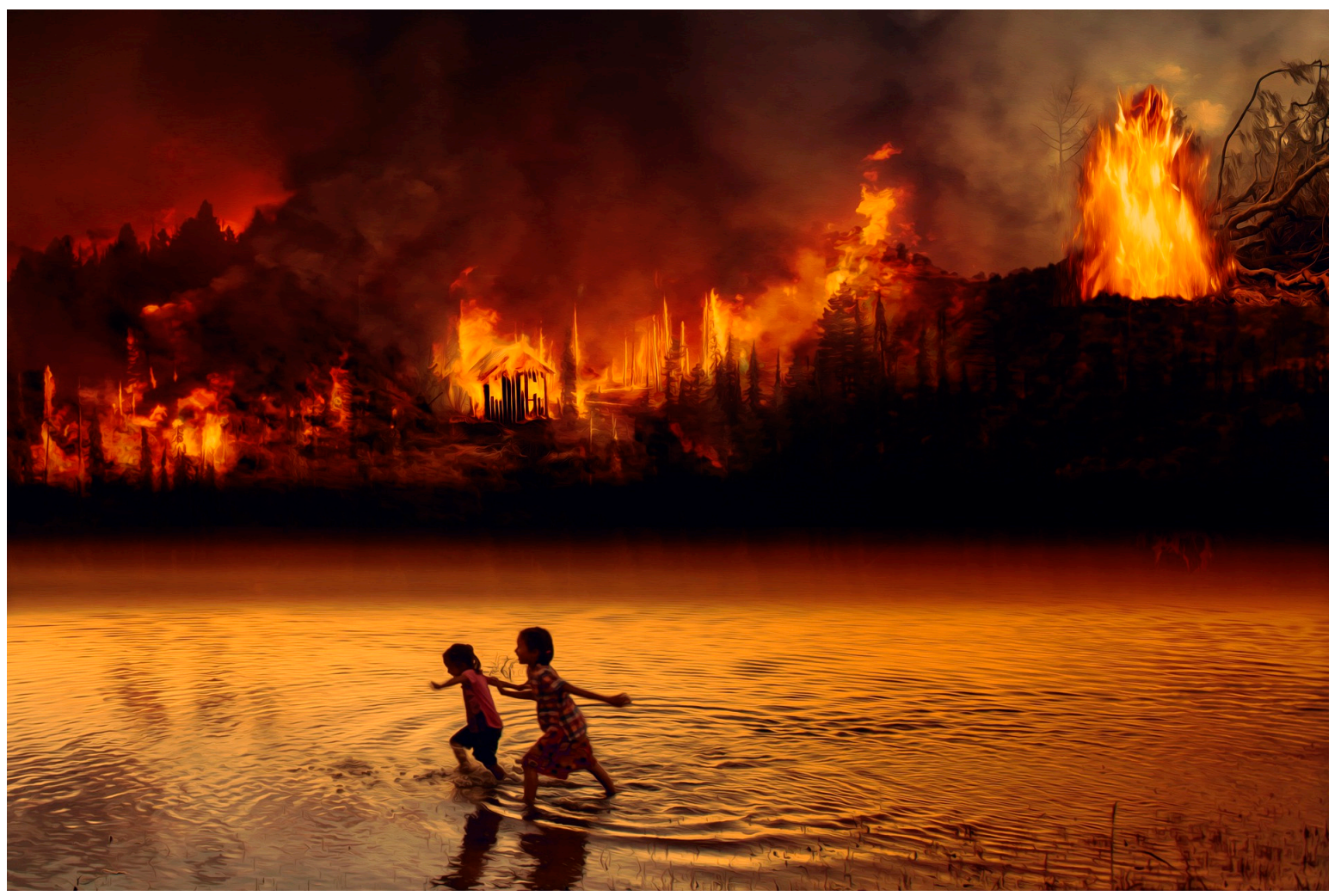

Figure 17. A snapshot from August 2019 Amazon rainforest fires [74].

\section{Conclusions}

The study at hand focused on tackling an important question of: "Are, and if yes how, cities considering the climate emergency in their local planning mechanisms?" The results of the study revealed that despite the existing federal presidential level climate crisis denial and efforts towards deforestation of Amazonia, the investigated municipalities have attempted to address the issue at least through municipal legislations, regulations and plans. These municipalities not only incorporate climatic issues in their urban planning and urban management regulations, but also contribute to the fulfillment of Brazil's climate commitments, more in terms of adaptation than in terms of mitigation, consistently with the findings of local and national emissions inventories.

Concerning possible policy improvements at the municipal level, the study recommends greater coordination between local health promotion and disaster management actions by the investigated cities. This is at utmost importance in order to foster urban resilience and sustainability. However, these municipalities' policies concentrate more on adaptation rather than mitigation [75]. Meaning that there is much more room for a better policy for adequately tackle the biggest problem of our 
time-i.e., climate crisis-further developing strategies in urban adaptation and resilience. According to the obtained results from our analysis, it is possible to draw the following insights and conclusions.

Firstly, decentralized cooperation and the edition of the National Policy on Climate Change (PNMC) were the main drivers for the structuring of local climate actions by the five investigated cities. However, with the new federal administration in office, the national climate change policy has the risk of staying current or not being endorsed and implemented [76].

Secondly, by including climate actions in their Master Plans, Land Use regulations and Sectoral Plans, the investigated cities do contribute to the compliance of Brazil's NDC, more in terms of Adaptation than Mitigation, coherently with the data of national and local GHG emissions inventories and with the guidelines of the PNMC and the National Adaptation Plan (PNA). It was not possible, however, to determine precisely to what extent-i.e., emissions percentages-the investigated cities can contribute to the national target of $37 \%$ of GHG emissions. It can only be inferred that local mitigation actions concentrate in Mobility and Waste Management policies.

Thirdly, even though the investigated Brazilian cities have included adaptation and resilience measures in their Master Plans, land use regulations and sectoral policies, there is significant room for improvements, especially considering that mitigation, not adaptation, was by far the most referenced axis in four of the five investigated Local Climate Plans.

Fourthly, even though cooperation was overall the least referenced climate action axis, all investigated cities have presented some references to cooperation actions apart from their respective GHGs inventories, what confirms some degree of engagement with the international community regarding climate change issues.

Fifthly, health, as expected, effectively integrates the Climate Plans, Master Plans, Land Use Regulations and Sectoral Plans of the five investigated cities, especially in Waste Management and Sanitation. Besides the climate emergency, due to inadequate infrastructure and informal housing-so-called Favelas of Brazil-health has been a major policy focus and concern in the nation.

Sixthly, the study findings reveal that Brazilian cities are rich in terms of policy but poor in terms of their implementation. Although the five investigated cities showed some connection points between their climate, public health, and disaster management policies, they should further coordinate and integrate these policies in order to develop urban resilience and foster SDGs fulfillment at the local level. These local level policy and implementation attempts are hoped to showcase promising results on the ground and generate motivation for other Brazilian municipalities, states and the federal government to further invest in tackling the climate crisis-that is upon Brazil $[77,78]$ and the entire globe. The results indicate that the investigated cities have the necessary tools to act on climate mitigation, adaptation and resilience, but assessing the effectiveness of these actions goes beyond the objectives and scope of the proposed research and could be developed by further studies on the matter.

Lastly, the literature clearly indicates that climate change and its catastrophic consequences are the inevitable harsh reality of our time $[79,80]$. In such dire straits, we need to move urgently from climate policy/agenda to climate action [81,82]. This is to say, the lip service (e.g., rhetoric and/or policy without effective implementation and impact) will not get the desired outcomes. Cities need to urgently lead the way in climate change action [83], however, they need to find ways to successfully implement policies as well. The road to successful implementation is highly bumpy, we need to find ways to transform barriers into enablers of action on climate change and sustainable urban development [84-86]. Citizens, scientist, institutions, policymaking, and multilevel governance structures along with good/honest politics are required for such immediate action and practice turnaround (i.e., changing the attitude, behavior, and choice)—both industrial and household [87,88].

Author Contributions: D.S. designed and led the research, under the supervision of A.P.; D.S. and A.P. jointly prepared the first draft of the manuscript; T.Y. and M.K. revised, and increased the rigor, relevance and reach of the manuscript. All authors read and approved the final version of the manuscript.

Funding: This research did not receive any specific grant from funding agencies in the public, commercial or not-for-profit sectors. 
Acknowledgments: The authors thank anonymous referees for their constructive comments on an earlier version of the manuscript.

Conflicts of Interest: The authors declare no conflict of interest.

\section{References}

1. Van Loon, A.F.; Gleeson, T.; Clark, J.; Van Dijk, A.I.; Stahl, K.; Hannaford, J.; Hannah, D.M. Drought in the Anthropocene. Nat. Geosci. 2016, 9, 89-91. [CrossRef]

2. Yigitcanlar, T.; Kamruzzaman, M.; Foth, M.; Sabatini-Marques, J.; Costa, E.; Ioppolo, G. Can cities become smart without being sustainable? A systematic review of the literature. Sustain. Cities Soc. 2019, 45, 348-365. [CrossRef]

3. Scranton, R. Learning to Die in the Anthropocene: Reflections on the End of a Civilization; City Lights Publishers: San Francisco, CA, USA, 2015.

4. Yigitcanlar, T.; Foth, M.; Kamruzzaman, M. Towards post-anthropocentric cities: Reconceptualising smart cities to evade urban ecocide. J. Urban Technol. 2019, 26, 147-152. [CrossRef]

5. Parmesan, C.; Yohe, G. A globally coherent fingerprint of climate change impacts across natural systems. Nature 2003, 421, 37. [CrossRef] [PubMed]

6. Burke, M.; Dykema, J.; Lobell, D.B.; Miguel, E.; Satyanath, S. Incorporating climate uncertainty into estimates of climate change impacts. Rev. Econ. Stat. 2015, 97, 461-471. [CrossRef]

7. Pecl, G.T.; Araújo, M.B.; Bell, J.D.; Blanchard, J.; Bonebrake, T.C.; Chen, I.C.; Falconi, L. Biodiversity redistribution under climate change: Impacts on ecosystems and human well-being. Science 2017, 355, eaai9214. [CrossRef] [PubMed]

8. Jakob, M.; Steckel, J.C. Implications of climate change mitigation for sustainable development. Environ. Res. Lett. 2016, 11, 104010. [CrossRef]

9. Yigitcanlar, T. Planning for smart urban ecosystems: Information technology applications for capacity building in environmental decision making. Theor. Empir. Res. Urban Manag. 2009, 4, 5-21.

10. Aldieri, L.; Carlucci, F.; Vinci, C.P.; Yigitcanlar, T. Environmental innovation, knowledge spillovers and policy implications: A systematic review of the economic effects literature. J. Clean. Prod. 2019, 239, 118051. [CrossRef]

11. Yigitcanlar, T.; Kamruzzaman, M.; Buys, L.; Ioppolo, G.; Sabatini-Marques, J.; da Costa, E.; Yun, J. Understanding 'smart cities': Intertwining development drivers with desired outcomes in a multidimensional framework. Cities 2018, 81, 145-160. [CrossRef]

12. Rottz, M.; Sell, D.; Pacheco, R.; Yigitcanlar, T. Digital commons and citizen coproduction in smart cities: Assessment of Brazilian municipal e-government platforms. Energies 2019, 12, 2813. [CrossRef]

13. Arbolino, R.; Carlucci, F.; Cira, A.; Ioppolo, G.; Yigitcanlar, T. Efficiency of the EU regulation on greenhouse gas emissions in Italy: The hierarchical cluster analysis approach. Ecol. Indic. 2017, 81, 115-123. [CrossRef]

14. Ingrao, C.; Messineo, A.; Beltramo, R.; Yigitcanlar, T.; Ioppolo, G. How can life cycle thinking support sustainability of buildings? Investigating life cycle assessment applications for energy efficiency and environmental performance. J. Clean. Prod. 2018, 201, 556-569. [CrossRef]

15. Yigitcanlar, T.; Sabatini-Marques, J.; da-Costa, E.M.; Kamruzzaman, M.; Ioppolo, G. Stimulating technological innovation through incentives: Perceptions of Australian and Brazilian firms. Technol. Forecast. Soc. Chang. 2019, 146, 403-412. [CrossRef]

16. Arbolino, R.; De Simone, L.; Carlucci, F.; Yigitcanlar, T.; Ioppolo, G. Towards a sustainable industrial ecology: Implementation of a novel approach in the performance evaluation of Italian regions. J. Clean. Prod. 2018, 178, 220-236. [CrossRef]

17. Zapf, M.; Pengg, H.; Weindl, C. How to Comply with the Paris Agreement Temperature Goal: Global Carbon Pricing According to Carbon Budgets. Energies 2019, 12, 2983. [CrossRef]

18. Yigitcanlar, T.; Kamruzzaman, M. Does smart city policy lead to sustainability of cities? Land Use Policy 2018, 73, 49-58. [CrossRef]

19. Manowska, A.; Nowrot, A. The Importance of Heat Emission Caused by Global Energy Production in Terms of Climate Impact. Energies 2019, 12, 3069. [CrossRef] 
20. Brasil. Sumário Executivo. Documento-Base para Subsidiar os Diálogos Estruturados Sobre a Elaboração de uma Estratégia de Implementação e Financiamento da Contribuição Nacionalmente Determinada do Brasil ao Acordo de Paris; Ministério do Meio Ambiente: Brasília, Brazil, 2017.

21. Octaviano, C.; Paltsev, S.; Gurgel, A.C. Climate change policy in Brazil and Mexico: Results from the MIT EPPA model. Energy Econ. 2016, 56, 600-614. [CrossRef]

22. Broto, V.C. Urban governance and the politics of climate change. World Dev. 2017, 93, 1-15. [CrossRef]

23. Hale, T. "All Hands-on Deck": The Paris Agreement and Nonstate Climate Action. Glob. Environ. Politics 2016, 16, 12-22. [CrossRef]

24. United Nations, General Assembly. Resolution Adopted by the General Assembly on 27 July 2012. 66/288. The Future We Want; United Nations: Washington, DC, USA, 2012.

25. United Nations, General Assembly. Resolution Adopted by the General Assembly on 25 September 2015; United Nations: Washington, DC, USA, 2015.

26. United Nations, General Assembly. Resolution Adopted by the General Assembly on 23 December 2016; 71/256. New Urban Agenda; United Nations: Washington, DC, USA, 2016.

27. Jacobi, P.; Sulaiman, S. Governança ambiental urbana em face das mudanças climáticas. Rev. USP 2016, 109, 133-142. [CrossRef]

28. Nobre, C. Mudanças climáticas globais: Possíveis impactos nos ecossistemas do país. Parcer. Estratégicas 2001, 6, 239-258.

29. Pessini, L.; Sganzerla, A. As mudanças climáticas e seus impactos no reino a vida: Perspectivas para um futuro não apocalíptico. Revista Iberoamericana de Bioética 2016, 2, 1-13.

30. Lahsen, M. A science-policy interface in the global south: The politics of carbon sinks and science in Brazil. Clim. Chang. 2009, 97, 339. [CrossRef]

31. Engle, N.L.; Lemos, M.C. Unpacking governance: Building adaptive capacity to climate change of river basins in Brazil. Glob. Environ. Chang. 2010, 20, 4-13. [CrossRef]

32. Yin, R.K. Case Study Research; Sage Publications: Thousand Oaks, CA, USA, 2003.

33. Owen, G.T. Qualitative methods in higher education policy analysis: Using interviews and document analysis. Qual. Rep. 2014, 19, 1-19.

34. Brasil. Lei 6.938 de 31 de Agosto de 1981. Available online: http://www.planalto.gov.br/ccivil_03/Leis/L6938. htm (accessed on 24 August 2019).

35. Brasil. Lei 10.257 de 10 de Julho de 2001-Estatuto da Cidade. Available online: http://www.planalto.gov.br/ ccivil_03/Leis/LEIS_2001/L10257.htm (accessed on 24 August 2019).

36. Yigitcanlar, T.; Metaxiotis, K.; Carrillo, F.J. Building Prosperous Knowledge Cities: Policies, Plans and Metrics; Edward Elgar: Cheltenham, UK, 2012.

37. Yigitcanlar, T. Position paper: Benchmarking the performance of global and emerging knowledge cities. Expert Syst. Appl. 2014, 41, 5549-5559. [CrossRef]

38. Intergovernmental Panel on Climate Change-IPCC. Global Warming of $1.5^{\circ} \mathrm{C}$ : An IPCC Special Report on the Impacts of Global Warming of $1.5^{\circ} \mathrm{C}$ above Pre-industrial Levels and Related Global Greenhouse Gas Emission Pathways, in the Context of Strengthening the Global Response to the Threat of Climate Change, Sustainable Development, and Efforts to Eradicate Poverty; Intergovernmental Panel on Climate Change: Geneva, Switzerland, 2018.

39. Pacheco, R.; Silva, C. Global Warming Potential of Biomass-to-Ethanol: Review and Sensitivity Analysis through a Case Study. Energies 2019, 12, 2535. [CrossRef]

40. Ministério da Ciência, Tecnologia, Inovação e Comunicação-MCTIC. Terceira Comunicaçãeo Nacional do Brasil à Convenção-Quadro das Nações Unidas sobre Mudança do Clima; MCTIC: Brasília, Brazil, 2018.

41. Azevedo, T. Emissões de GEE do Brasil e suas Implicações para Políticas Públicas e a Contribuição Brasileira para o Acordo de Paris; Documento síntese; Período 1970-2015; Observatório do Clima; SEEG: Brasilia, Brazil, 2017.

42. Malhi, Y.; Roberts, J.T.; Betts, R.A.; Killeen, T.J.; Li, W.; Nobre, C.A. Climate change, deforestation, and the fate of the Amazon. Science 2008, 319, 169-172. [CrossRef]

43. Caviglia-Harris, J.L. Agricultural innovation and climate change policy in the Brazilian Amazon: Intensification practices and the derived demand for pasture. J. Environ. Econ. Manag. 2018, 90, 232-248. [CrossRef]

44. Farias, A.R.; Mingoti, R.; Valle, L.D.; Spadotto, C.A.; Lovisi Filho, E. Comunicado Técnico. Identificação, Mapeamento e Quantificação das Áreas Urbanas do Brasil; Embrapa: Brasilia, Brazil, 2017.

45. SEEG. Plataforma SEEG Brasil. Available online: http://plataforma.seeg.eco.br/ (accessed on 24 August 2019). 
46. De Azevedo, T.R.; Junior, C.C.; Junior, A.B.; dos Santos Cremer, M.; Piatto, M.; Tsai, D.S.; Barreto, P.; Martins, H.; Sales, M.; Galuchi, T.; et al. SEEG initiative estimates of Brazilian greenhouse gas emissions from 1970 to 2015. Sci. Data 2018, 5, 180045. [CrossRef] [PubMed]

47. Souza, S. Frota de Manaus em Circulação Supera Marca de 713 mil Veículos; A Crítica: Manaus, Brazil, 2017. Available online: https://www.acritica.com/channels/manaus/news/frota-de-manaus-superamarca-de-713mil-veiculos (accessed on 24 August 2019).

48. Suframa. O que é o Projeto ZFM? Available online: http://site.suframa.gov.br/assuntos/modelo-zona-francade-manaus/o-que-e-o-projeto-zfm (accessed on 24 August 2019).

49. Nobre, C.A.; Sampaio, G.; Borma, L.S.; Castilla-Rubio, J.C.; Silva, J.S.; Cardoso, M. Land-use and climate change risks in the Amazon and the need of a novel sustainable development paradigm. Proc. Natl. Acad. Sci. USA 2016, 113, 10759-10768. [CrossRef] [PubMed]

50. Liu, Y.; Brito, J.; Dorris, M.R.; Rivera-Rios, J.C.; Seco, R.; Bates, K.H.; Goldstein, A.H. Isoprene photochemistry over the Amazon rainforest. Proc. Natl. Acad. Sci. USA 2016, 113, 6125-6130. [CrossRef] [PubMed]

51. Prefeitura de Curitiba. 20 e 30 Inventários de Gases de Efeito Estufa para a Cidade de Curitiba; Prefeitura Municipal de Curitiba: Curitiba, Brazil, 2016.

52. Abreu, V. Produção de $\mathrm{CO}_{2}$ em Goiânia é 28.5\% acima da média nacional; O Popular: Goiânia, Brazil, 2017.

53. Prefeitura de Salvador. Inventário de Emissões dos Gases do Efeito Estufa de Salvador; Secretaria Cidade Sustentável: Salvador, Brazil, 2016.

54. Instituto Ekos Brasil \& Geolock Consultoria e Engenharia Ambiental. Inventário de Emissões e Remoções Antrópicas de Gases de Efeito Estufa do Município de São Paulo de 2003 a 2009 com Atualização para 2010 e 2011 nos Setores Energia e Resíduos; ANTP: São Paulo, Brazil, 2013.

55. Governo do Estado da Bahia. Primeiro Inventário de Emissões Antrópicas de Gases de Efeito Estufa do Estado da Bahia; SEMA: Salvador, Brazil, 2010. Available online: http://www.consultaesic.cgu.gov.br/busca/dados/Lists/ Pedido/Attachments/456145/RESPOSTA_PEDIDO_1\%2020100915\%20inventario\%20emissoes\%20BA.pdf (accessed on 24 August 2019).

56. Governo do Estado de São Paulo. Comunicação Estadual. 1o Inventário de Emissões Antrópicas de Gases de Efeito Estufa Diretos e Indiretos do Estado de São Paulo; SMA; CETESB: São Paulo, Brazil, 2011.

57. Governo do Estado do Paraná. Inventário de Emissões Antrópicas Diretas e Indiretas de Gases de Efeito Estufa 2005-2012. Resumo Executivo; SEMA: Curitiba, Brazil, 2015.

58. World Health Organization-WHO. Ambient air Pollution: A Global Assessment of Exposure and Burden of Disease; World Health Organization: Geneva, Switzerland, 2016.

59. Saldiva, P. Vida Urbana e Saúde. Os Desafios dos Habitantes das Metrópoles; Contexto: São Paulo, Brazil, 2018.

60. Brasil. Constituição da Republica Federativa do Brasil de 1988. Available online: http://www.planalto.gov. br/ccivil_03/Constituicao/Constituicao.htm (accessed on 24 August 2019).

61. Brasil. Lei 11.445 de 5 de Janeiro de 2007. Available online: http://www.planalto.gov.br/ccivil_03/_Ato20072010/2007/Lei/L11445.htm (accessed on 24 August 2019).

62. Brasil. Lei 12.305 de 2 de Agosto de 2010. Available online: http://www2.mma.gov.br/port/conama/legiabre. cfm?codlegi=636 (accessed on 24 August 2019).

63. Brasil. Lei 12.587 de 3 de Janeiro de 2012. Available online: http://www.planalto.gov.br/ccivil_03/_Ato20112014/2012/Lei/L12587.htm (accessed on 24 August 2019).

64. Brasil. Lei 11.124 de 16 de Junho de 2005. Available online: http://www.planalto.gov.br/ccivil_03/_Ato20042006/2005/Lei/L11124.htm (accessed on 24 August 2019).

65. Brasil. Lei 12.608 de 10 de Abril de 2012. Available online: http://www.planalto.gov.br/ccivil_03/_Ato20112014/2012/Lei/L12608.htm (accessed on 24 August 2019).

66. Brasil. Lei 8.080 de 19 de Setembro de 1990. Available online: http://www.planalto.gov.br/ccivil_03/leis/ L8080.htm (accessed on 24 August 2019).

67. IBGE. População em Áreas de Risco no Brasil; IBGE: Rio de Janeiro, Brazil, 2018.

68. Brasil. Lei 12.187 de 29 de Dezembro de 2009. Available online: http://www.planalto.gov.br/ccivil_03/ _Ato2007-2010/2009/Lei/L12187.htm (accessed on 24 August 2019).

69. Rei, F.; Gonçalves, A.F.; de Souza, L.P. Acordo de Paris: Reflexões e Desafios para o Regime Internacional de Mudanças Climáticas. Veredas Do Direito 2017, 14, 81-99. [CrossRef]

70. Ministério do Meio Ambiente (MMA). Plano Nacional de Adaptação à Mudança do Clima—Sumário Executivo; Ministério do Meio Ambiente: Brasília, Brazil, 2016. 
71. Ministério da Saúde. Plano Setorial da Saúde para Mitigação e Adaptação à Mudança do Clima; Ministério da Saúde: Brasília, Brazil, 2013.

72. Maglio, I.; Philippi, A., Jr. Sustentabilidade Ambiental e Mudanças Climáticas. In Gestão Urbana e Sustentabilidade; Philippi, A., Jr., e Bruna, G., Eds.; Manole: Barueri, Brazil, 2018; pp. 428-453.

73. Yigitcanlar, T.; Sabatini-Marques, J.; Lorenzi, C.; Bernardinetti, N.; Schreiner, T.; Fachinelli, A.; Wittmann, T. Towards smart Florianópolis: What does it take to transform a tourist island into an innovation capital? Energies 2018, 11, 3265. [CrossRef]

74. Sopala, R. A copyright free image by of 2019 Amazon fires. Available online: https://pixabay.com/photos/ fire-forest-fire-children-fear-4429478/ (accessed on 3 September 2019).

75. Galán-Martín, A.; Pozo, C.; Azapagic, A.; Grossmann, I.E.; Mac Dowell, N.; Guillén-Gosálbez, G. Time for global action: An optimised cooperative approach towards effective climate change mitigation. Energy Environ. Sci. 2018, 11, 572-581. [CrossRef]

76. Rochedo, P.R.; Soares-Filho, B.; Schaeffer, R.; Viola, E.; Szklo, A.; Lucena, A.F.; Rathmann, R. The threat of political bargaining to climate mitigation in Brazil. Nat. Clim. Chang. 2018, 8, 695-698. [CrossRef]

77. Eduardo, V.; Franchini, M. Brazil and Climate Change: Beyond the Amazon; Routledge: Abingdon, UK, 2017.

78. Giannini, T.C.; Costa, W.F.; Cordeiro, G.D.; Imperatriz-Fonseca, V.L.; Saraiva, A.M.; Biesmeijer, J.; Garibaldi, L.A. Projected climate change threatens pollinators and crop production in Brazil. PLoS ONE 2017, 12, e0182274. [CrossRef] [PubMed]

79. Zheng, B.; Xu, Q.; Shen, Y. The relationship between climate change and quaternary glacial cycles on the Qinghai-Tibetan Plateau: Review and speculation. Quat. Int. 2002, 97, 93-101. [CrossRef]

80. Hartmann, B. Rethinking climate refugees and climate conflict: Rhetoric, reality and the politics of policy discourse. J. Int. Dev. J. Dev. Stud. Assoc. 2010, 22, 233-246. [CrossRef]

81. Spratt, D.; Sutton, P. Climate Code Red: The Case for Emergency Action; Scribe Publications: Sidney, Australia, 2008.

82. Tang, Z.; Brody, S.D.; Quinn, C.; Chang, L.; Wei, T. Moving from agenda to action: Evaluating local climate change action plans. J. Environ. Plan. Manag. 2010, 53, 41-62. [CrossRef]

83. Rosenzweig, C.; Solecki, W.; Hammer, S.A.; Mehrotra, S. Cities lead the way in climate-change action. Nature 2010, 467, 909-911. [CrossRef] [PubMed]

84. Burch, S. Transforming barriers into enablers of action on climate change: Insights from three municipal case studies in British Columbia, Canada. Glob. Environ. Chang. 2010, 20, 287-297. [CrossRef]

85. Yigitcanlar, T. Rethinking Sustainable Development: Urban Management, Engineering, and Design; IGI Global: Hershey, PA, USA, 2010.

86. Yigitcanlar, T. Sustainable Urban and Regional Infrastructure Development: Technologies, Applications and Management: Technologies, Applications and Management; IGI Global: Hershey, PA, USA, 2010.

87. Selin, H.; VanDeveer, S.D. Changing Climates in North American Politics: Institutions, Policymaking, and Multilevel Governance; MIT Press: Cambridge, MA, USA, 2009.

88. Shove, E. Beyond the ABC: Climate change policy and theories of social change. Environ. Plan. A 2010, 42, 1273-1285. [CrossRef]

(C) 2019 by the authors. Licensee MDPI, Basel, Switzerland. This article is an open access article distributed under the terms and conditions of the Creative Commons Attribution (CC BY) license (http://creativecommons.org/licenses/by/4.0/). 